\title{
Indeks razvijenosti: analiza temeljnog instrumenta hrvatske regionalne politike
}

Perišić, Ana; Wagner, Vanja

Source / Izvornik: Odabrani prijevodi, 2015, 6, 1 - 24

Journal article, Published version

Rad u časopisu, Objavljena verzija rada (izdavačev PDF)

https://doi.org/10.3326/op.30

Permanent link / Trajna poveznica: https:/urn.nsk.hr/urn:nbn:hr:242:728602

Rights / Prava: Attribution-NonCommercial-NoDerivatives 4.0 International/ImenovanjeNekomercijalno-Bez prerada 4.0 međunarodna

Download date / Datum preuzimanja: 2023-04-26

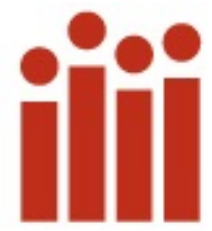

Repository / Repozitorij:

Institute of Public Finance Repository

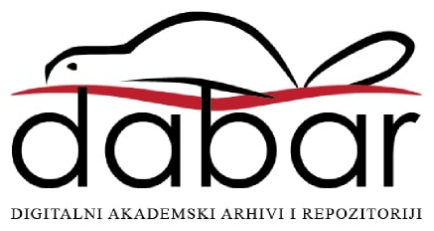


Institut za

javne financije

Smičiklasova 2I | Zagreb

www.ijf.hr | ured@ijf.hr

T: oI/4886-444 | F: oI/48I9-365

\section{OdABRANI}

\section{PRIJEVODI}

ISSN I847-7445

BR. 30/I5

citirati: Perišić, A. i Wagner, V. 2015. Development index: analysis of the basic instrument of Croatian regional policy. Financial Theory and Practice, 39 (2), str. 205-236.

http://www.fintp.hr/upload/files/ft p/2015/3/perisic_wagner.pdf

Svi Odabrani prijevodi dostupni su na: http://www.ijf.hr/hr/publikacije/ca sopisi/I2/odabrani-prijevodi/III/

\section{INDEKS RAZVIJENOSTI: ANALIZA TEMELJNOG INSTRUMENTA HRVATSKE REGIONALNE POLITIKE}

\author{
MAG. MATH. ANA PERIŠIĆ ${ }^{*}$ \\ MAG. MATH. VANJA WAGNER*
}

PRETHODNO PRIOPĆENJE*

JEL: RI, CI8, C43

DOI: $10.3326 /$ op.30

\section{SAŽETAK}

Ocjenjivanje i kategorizacija hrvatskih jedinica lokalne i regionalne samouprave prema stupnju razvijenosti temelji se na indeksu razvijenosti, temeljnom instrumentu hrvatske regionalne politike. Indeks razvijenosti je kompozitni pokazatelj koji se računa kao ponderirani prosjek pet socio-ekonomskih pokazatelja. Cilj rada je ispitati neizvjesnost i osjetljivost indeksa razvijenosti s obzirom na metodologiju izračuna indeksa i pokazatelje uključene u izračun te dati korisne smjernice za njegovo unaprjeđenje. U radu je dan kritički osvrt na metodološki pristup u izračunu indeksa razvijenosti hrvatskih teritorijalnih jedinica, ukazano je na postojanje izdvojenica i pojavu multikolinearnosti pokazatelja. Predložen je empirijski i relativno objektivniji pristup za određivanje pondera metodom multivarijatne analize. Analiza neizvjesnosti i osjetljivosti provedene su pomoću Monte Carlo simulacija i procedura baziranih na varijanci. Za jedinice lokalne i regionalne samouprave predložene su intervalne procjene za vrijednost indeksa razvijenosti kao alternativa procjeni jednim brojem.

Ključne riječi: indeks razvijenosti, kompozitni pokazatelji, multivarijatna analiza, analiza neizvjesnosti, analiza osjetlivosti, Hrvatska

"Autorice zahvaljuju dr. sc. Dubravki Šišak Jung kao i dvojici anonimnih recenzenata na

korisnim komentarima i sugestijama.

"* Primljeno: I. lipnja 2014.

Prihvaćeno: 2I. studenog 2014.

Rad je prijavljen za godišnju nagradu "Zaklade prof. dr. Marijan Hanžeković” za 2oI4. godinu.

Ana PERIŠIĆ

Veleučilište u Šibeniku, Trg Andrije Hebranga II, 22000 Šibenik

e-mail: sisak@vus.hr

Vanja WAGNER

Sveučilište u Zagrebu, Prirodoslovno-matematički fakultet-Matematika, Bijenička cesta 30, Ioooo Zagreb

e-mail: wagner@math.hr 


\section{UVOD}

Briga za gospodarskim razvojem svih krajeva u Hrvatskoj te poticanje gospodarskog razvitka i socijalnog blagostanja građana predstavlja ustavnu kategoriju. Ocjenjivanje razine razvijenosti teritorijalnih jedinica je presudno u regionalnom planiranju i politici razvoja te je ključan kriterij za alokaciju različitih strukturnih fondova i državnih pomoći (Cziraky et al., 2005.). Loša socioekonomska situacija ima za posljedicu slabe fiskalne kapacitete lokalnih jedinica, što ih čini ovisnim o državnim dotacijama i nesposobnim za značajnije poticanje razvoja (Puljiz, 20o9.). Stručnjaci su kriterije za dobivanje državne pomoći često ocjenjivali kao nejasne i netransparentne (Ott i Bajo, 200I.; Bronić, 2008., 20I0.).

Donošenjem Zakona o regionalnom razvoju (ZRR) 20o9. kao temelj za ocjenjivanje i kategorizaciju jedinica lokalne samouprave (JLS) i jedinica regionalne samouprave (JRS) uveden je indeks razvijenosti. Indeks razvijenosti je kompozitni pokazatelj koji se računa kao ponderirani prosjek pet socioekonomskih pokazatelja:

(I) prosječan dohodak per capita $\left(X_{\mathrm{I}}\right)$,

(2) prosječni izvorni prihodi JLS-a odnosno JRS-a per capita $\left(X_{2}\right)$,

(3) prosječna stopa nezaposlenosti $\left(X_{3}\right)$,

(4) kretanje stanovništva $\left(X_{4}\right)$,

(5) udio obrazovanog stanovništva u ukupnom stanovništvu dobi I6-65 godina $\left(X_{5}\right)$.

Indeks razvijenosti lokalne jedinice $c$ izračunava se pomoću formule:

$$
I_{c}=0,25 x_{c 1}+0,15 x_{c 2}+0,3 x_{c 3}+0,15 x_{c 4}+0,15 x_{c 5} \quad c=1,2, \ldots, m
$$

gdje su $x_{c i}, i=1,2, \ldots, 5$ normalizirane vrijednosti pokazatelja $X_{i}$ za jedinicu $c$. Pokazatelje za izračun indeksa razvijenosti, udio pojedinog pokazatelja u ukupnoj vrijednosti indeksa razvijenosti i druga pitanja s tim u svezi uređuje Vlada Uredbom (Uredba o indeksu razvijenosti, 20Io.). Temeljem indeksa razvijenosti JLS-i su kategorizirani u pet skupina, dok su JRS-i kategoriziranei u 4 skupine. Status potpomognutog područja stječu JLS-i kategorizirani u skupine I i II, te JRS-i kategorizirani u skupinu I. Postupak ocjenjivanja i razvrstavanja JLS-a i JRS-a prema indeksu razvijenosti provodi se svake tri godine.

Loše konstruirani ili krivo interpretirani kompozitni indeksi mogu navoditi na pogrešnu politiku upravljanja razvojem, stoga je validacija takvih modela od iznimne važnosti. Budući da takvi modeli ne mogu biti validirani u smislu dokazivanja njihove ispravnosti (Oreskes et al., 1994.), opravdanost kompozitnog indikatora leži u njegovoj prikladnosti namijenjenoj upotrebi i prihvaćenosti od strane stručnjaka (Rosen, 199i.). Stoga je ispravnije tvrditi kako model može biti potvrđen ako prođe testove koji ocjenjuju sposobnost modela u uvjerljivom i parsimonijskom objašnjavanju ili predviđanju sistema (Saisana i Saltelli, 2008.). U svrhu maksimiziranja korisnosti indeksa i minimiziranja njihove zlouporabe, kompozitni pokazatelji moraju biti razvijeni korištenjem najboljih mogućih parametara, transparentno dokumentirani i validirani korištenjem prikladnih metoda analize neizvjesnosti i analize osjetljivosti. Analiza neizvjesnosti fokusirana je na ispitivanje kako se neizvjesnost ulaznih parametara prenosi kroz strukturu kompozitnih pokazatelja i utječe na njegovu vrijednost (Saisana et al., 2005.). Analizom osjetljivosti ispituju se posljedice varijabilnosti i interakcija pokazatelja kao mogućih izvora nestabilnosti. I dok se u većini slučajeva analiza neizvjesnosti i analiza osjetljivosti provode odvojeno, sinergijsko provođenje obaju analiza u razvijanju kompozitnog indeksa može poboljšati njegovu strukturu (Nardo et al., 2005.; Saisana et al., 2005.; Tarantola et al., 2000.; Gall, 
2007.). Saisana et al. (2005.) provode analizu neizvjesnosti i analizu osjetljivosti kompozitnog indeksa koristeći Monte Carlo simulacije i procedure bazirane na varijanci. Paruolo et al. (2013.) predlažu Pearsonov koeficijent korelacije kao mjeru važnosti varijabli te provode analizu osjetljivosti baziranu na procedurama na varijanci nad više različitih kompozitnih indeksa. Hoyland et al. (20I2.) kritiziraju pristup agregiranju varijabli $u$ kompozitni indeks u kojem nije uključena neizvjesnost i predlažu procjenu neizvjesnosti koristeći Bayesovski pristup te pristup apliciraju na tri kompozitna indeksa. Nardo et al. (2008.) daju smjernice u konstrukciji indeksa razvijenosti i preporuke za provedbu analize neizvjesnosti i analize osjetljivosti. Uz brojne radove koji se bave analizom regionalnih razlika $\mathrm{u}$ Hrvatskoj (npr. Rimac et al., I992.; Grčić i Filipić, 2002.; Cziraky et al., 2003., 2005.; Perišić, 2014.) i pitanjem kategorizacije JLS-a i JRS-a prema socio-ekonomskoj razvijenosti izostali su radovi koji analiziraju osjetljivost kategorizacija na promjene u sustavu te ispituju osjetljivost i neizvjesnost metodologije izračuna indeksa razvijenosti.

Predmet ovoga rada je ispitivanje neizvjesnosti i osjetljivosti kategorizacije JLS-a i JRS-a prema socioekonomskoj razvijenosti. Osnovni ciljevi rada su ispitati neizvjesnost indeksa razvijenosti s obzirom na metodološki pristup i osjetljivost indeksa s obzirom na pokazatelje uključene $u$ izračun te dati korisne smjernice za unaprjeđenje indeksa. Također, ciljevi rada obuhvaćaju i utvrđivanje strukture podataka primjenom multivarijatnih metoda. U radu je prikazana metodologija izračuna indeksa razvijenosti, te je dan kritički osvrt i preporuke za njeno unaprjeđenje. Neizvjesnost i osjetljivost kompozitnih indeksa važna je tema zbog svoje velike generalnosti te može biti primijenjena $u$ različitim područjima znanosti i struke. Metode prikazane u ovom radu mogu biti korisne donosiocima odluka i stručnjacima u ocjenjivanju pouzdanosti kompozitnih indeksa.

\section{Metodologija MODELiRANJA REgionalnog RAZVOJA U HRVATSKOJ}

\section{I. RAZVOJ POLITIKE REGIONALNOG RAZVOJA}

Regionalna politika u svojim počecima bila je usmjerena na obnovu ratom razorenih područja. Iskorak u regionalnoj politici učinjen je donošenjem Zakona o područjima posebne državne skrbi (PPDS) i njegovim izmjenama i dopunama. Ta su područja osnovana u svrhu poticanja njihovog bržeg razvoja te stoga imaju povlašteni položaj u financiranju (Ott i Bajo, 20oI.). Prema zakonu o PPDS-u, donesenim 1996., formirane su tri skupine potpomognutih lokalnih jedinica. Prve dvije skupine određene su na temelju štete prouzročene Domovinskim ratom. Treća se skupina, utvrđena 2002., sastoji od jedinica koje zaostaju u razvoju na temelju četiri kriterija: ekonomske razvijenosti, strukturnih teškoća, demografskog i posebnog kriterija (Bronić, 2008.). Upravo je uvođenje socioekonomskih kriterija korak naprijed u vođenju regionalne politike. U definiranju treće skupine PPDSa korišteno je čak II pokazatelja: dohodak per capita, udio osoba koji ostvaruju prihode u cijeloj populaciji, izvorni prihodi lokalnih jedinica per capita, stopa nezaposlenosti, stopa zaposlenosti, socijalna pomoć per capita, opće kretanje stanovništva, stopa obrazovanosti, gustoća stanovništva, indeksi starenja stanovništva i vitalni indeks (Puljiz et al., 2005.). Također, korištena su dva posebna kriterija vezana uz pogranični položaj lokalne jedinice i postojanje minski sumnjivih područja. $\mathrm{Na}$ područjima posebne državne skrbi nalazilo se ukupno I85 jedinica lokalne samouprave; u prvoj skupini 50 JLS-a, u drugoj skupini 6I JLS, a u trećoj skupini nalazile su se 74 JLS-a. Kriteriji za dobivanje statusa PPDS uglavnom nisu bili povezani sa stvarnim socio-ekonomskim pokazateljima pa su se na tim područjima nalazile i gospodarski nadprosječno razvijene lokalne jedinice (Bajo i Primorac, 2013.). Pristup regionalnom razvoju koji je proizašao iz centralnog planiranja bio je 
nekonzistentan te su mu nedostajali jasno definirani ciljevi, dionici i instrumenti (Maleković et al., 20II.). Stoga je bilo potrebno promijeniti zakone vezane uz regionalnu politiku koja se često vodila $u$ okviru politike fiskalnog izravnanja i obratno, zbog čega su se instrumenti i ciljevi tih politika često sukobljavali, a učinci poništavali uz visoke troškove za državni proračun. Uvođenje jednostavnijeg i transparentnijeg sustava fiskalnog izravnanja utemeljenog na kvalitetnim kriterijima i fiskalnim instrumentima i dalje ostaje izazov za Vladu (Bajo i Primorac, 2013.).

Uspostava cjelovitog i koherentnog sustava upravljanja regionalnim razvojem na načelima suvremene regionalne politike podudara se s početkom pripremnih aktivnosti za pristupanje Hrvatske Europskoj Uniji (Sumpor et al., 2012). Temelj upravljanja politikom regionalnog razvoja postavlja se donošenjem Zakona o regionalnom razvoju (ZRR) krajem 2009., kojim se uređuju ciljevi i načela upravljanja regionalnim razvojem. Posebna novina je uvođenje indeksa razvijenosti kao temelja za ocjenjivanje razine socio-ekonomskog razvoja i ocjenjivanje stupnja razvijenosti ne samo JLS-a već i JRS-a te kategorizacija potpomognutih područja na temelju vrijednosti indeksa razvijenosti. Ministarstvo regionalnog razvoja i fondova Europske unije (MRRFEU) ocjenjuje kako korištenje jedinstvenog sustava ocjenjivanja razvijenosti svih teritorijalnih jedinica temeljenog na indeksu razvijenosti doprinosi jednostavnosti i transparentnosti cjelokupnog sustava, čime se omogućava bolje usmjeravanje poticaja i stječe kvalitetnija podloga za uključivanje i isključivanje jedinica iz sustava potpomognutih područja o kojima država dodatno skrbi (MRRFEU, 2OI2.).

Potpomognuta područja određena indeksom razvijenosti trebala su zamijeniti PPDS, no zapravo je došlo do paralelnog egzistiranja različitih kategorija slabije razvijenih područja. Donošenjem novog Zakona o regionalnom razvoju, taj će višegodišnji problem biti riješen te će biti uveden jedinstveni sustav ocjenjivanja razvijenosti teritorijalnih jedinica primjenjiv na čitavu državu. Primjena mjera na temelju novog ZRR-a očekuje se 20I5. Neke od glavnih novina koje donosi novi Zakon su uvođenje kategorije urbanog područja (i dodatno među njima aglomeracijskih središta), osnivanje Savjeta za regionalni razvoj i vezivanje svih budućih mjera poticanja razvoja za indeks razvijenosti kao temeljni instrument utvrđivanja stupnja razvijenosti svih JLS-a i JRS-a (MRRFEU, 2013c.). Promjenama zakona o PPDS-u, Zakona o regionalnom razvoju, Zakona o brdsko-planinskim područjima i Zakona o porezu na dobit i dohodak, Vlada nastoji uskladiti porezne olakšice i dodjelu pomoći lokalnim jedinicama iz državnog proračuna s njihovim stupnjem razvijenosti mjerenim indeksom razvijenosti. Glavne promjene u dodjeljivanju pomoći JLS-u su preusmjeravanje pomoći iz državnog proračuna koja se dodjeljivala $u$ visini poreza na dobit $u$ JLS-u prema indeksu razvijenosti i promjene visine osobnog odbitka (Bajo i Primorac, 2013.). Tako će visina pomoći izražena u postotku prihoda od poreza na dobit za jedinice I. i II. skupine iznositi Ioo\%, dok će za skupine III, IV i V ti postoci iznositi redom 75\%, 60\% i 40\%. Ograničenja ovakve raspodjele vidljiva su na primjeru općine Tovarnik koja će s indeksom razvijenosti $74,82 \%$ imati pravo na visinu pomoći u iznosu od IOO\%, dok će grad Ozalj s indeksom razvijenosti 75,o8\% imati pravo na pomoć u visini 75\% prihoda od dohotka. Zbog ovakvih rubnih primjera uvođenje linearnih odnosno po dijelovima linearnih odbitaka pridonijelo bi stvaranju pravednijeg sustava pomoći. Donošenjem novog Zakona o regionalnom razvoju prekinut će se paralelno egzistiranje dvaju zakona u kojima se definiraju jedinice koje zaostaju u razvoju. Ipak, PPDSi ponovo imaju poseban status u ocjenjivanju područja koja zaostaju u razvoju temeljem indeksa razvijenosti. Uredbom o izmjeni i dopunama Uredbe o indeksu razvijenosti određeno je kako se jedinicama s područja od posebne državne skrbi vrijednost indeksa razvijenosti umanjuje za Io postotnih bodova (korigirani indeks) ako njihov indeks razvijenosti prelazi 75\% (Uredba o izmjeni i 
dopunama Uredbe o indeksu razvijenosti, 2013.). U radu će biti promatrana dva indeksa JLS-a: nekorigirani indeks $I^{V}$ (bez umanjenja za Io postotnih bodova za PPDS) i korigirani indeks razvijenosti $I^{K V}$ (s umanjenjem za Io postotnih bodova za PPDS).

Metodologija indeksa izračunatog za period 20IO.-2012. razlikuje se od one vezane za indeks izračunat za period 2006.-2008. Uredbom o izmjeni i dopunama Uredbe o indeksu razvijenosti donesene su dvije značajne izmjene: iz izračuna izvornih prihoda per capita isključeni su prihodi od prodaje nefinancijske imovine te se vrijednost indeksa razvijenosti umanjuje za Io postotnih bodova za JLS-e koje su Zakonom o PPDS-u razvrstane u prvu i drugu skupinu PPDS-a, a kojima indeks razvijenosti prelazi 75\% prosjeka države (Uredba o izmjeni i dopunama Uredbe o indeksu razvijenosti, 20I3.). Prvom navedenom izmjenom onemogućen je utjecaj kratkoročnih izvora financiranja $u$ proračunskim prihodima na veličinu indeksa razvijenosti. Drugom izmjenom pokušalo se osigurati da ratom razorene JLS-e koje ne bilježe značajno viša odstupanja u socio-ekonomskoj razvijenosti u odnosu na prosjek države zadrže status potpomognutog područja. Ovom je izmjenom za 24 JLS-a koji su svrstane u prvu ili drugu skupinu PPDS-a osigurana kategorizacija u skupinu koja zaostaje $u$ razvoju, iako prema vrijednosti originalnog indeksa pripadaju skupinama srednjeg ili visokog stupnja razvijenosti.

\subsection{KATEGORIZAGIJA JEDINIGA LOKALNE I REGIONALNE SAMOUPRAVE PREMA INDEKSU RAZVIJENOSTI}

Jedinice lokalne samouprave razvrstavaju se prema vrijednosti indeksa razvijenosti u pet skupina. U tablici I dane su granične vrijednosti indeksa razvijenosti za JLS-e po skupinama, broj JLS-a kategoriziranih u pojedinu skupinu $(N)$, prosječne vrijednosti pokazatelja $X_{\mathrm{I}}, . ., X_{5}$ i standardne devijacije (u zagradama). Upravo standardne devijacije ukazuju na veliku heterogenost skupina.

\section{TABLIGA I.}

Kategorizacija JLS-a prema indeksu razvijenosti

\begin{tabular}{|c|c|c|c|c|c|c|c|}
\hline Skupina & Vrijednost indeksa (\%) & $N$ & $X_{1}$ & $X_{2}$ & $X_{3}(\%)$ & $X_{4}$ & $X_{5}(\%)$ \\
\hline I & $<50$ & 47 & $\begin{array}{l}\text { I3.049,28 } \\
(2.146,69)\end{array}$ & $\begin{array}{c}748,87 \\
(288,98)\end{array}$ & $\begin{array}{l}37,67 \\
(6,59)\end{array}$ & $\begin{array}{l}86,2 \mathrm{O} \\
(\mathrm{II}, \mathrm{OI})\end{array}$ & $\begin{array}{c}54,07 \\
(8,7)\end{array}$ \\
\hline II & $\langle 50,75\rangle$ & $2 \mathrm{I} 7$ & $\begin{array}{c}\text { I8.095,3 } \\
(3.333,85)\end{array}$ & $\begin{array}{c}\text { I.O2O,29 } \\
(472,4)\end{array}$ & $\begin{array}{c}22,89 \\
(6,3)\end{array}$ & $\begin{array}{l}92,83 \\
(8,9 \mathrm{I})\end{array}$ & $\begin{array}{c}62, \mathrm{I} 7 \\
(8, \mathrm{I})\end{array}$ \\
\hline III & $\langle 75$, IOO $\rangle$ & 173 & $\begin{array}{l}23 \cdot 355,31 \\
(3668,74)\end{array}$ & $\begin{array}{c}\text { I.9I2,6 } \\
\text { (I064,74) }\end{array}$ & $\begin{array}{c}\mathrm{I} 4,89 \\
(4,5)\end{array}$ & $\begin{array}{l}99,92 \\
(9,27)\end{array}$ & $\begin{array}{c}72 \\
(6,78)\end{array}$ \\
\hline IV & $\langle\mathrm{IOO}, \mathrm{I} 25\rangle$ & 93 & $\begin{array}{c}28.557, \text { II } \\
(4.426,46)\end{array}$ & $\begin{array}{l}3.556,06 \\
(1.179,26)\end{array}$ & $\begin{array}{c}\text { IO,84 } \\
(3,6)\end{array}$ & $\begin{array}{l}\text { IO8,I } \\
(\mathrm{I} 2, \mathrm{I} 5)\end{array}$ & $\begin{array}{c}80,35 \\
(5, \mathrm{I})\end{array}$ \\
\hline $\mathrm{V}$ & $>\mathrm{I} 25$ & 26 & $\begin{array}{c}29.938,73 \\
(6.000,14)\end{array}$ & $\begin{array}{c}7.060,54 \\
(1.359,8)\end{array}$ & $\begin{array}{c}8 \\
(3, I)\end{array}$ & $\begin{array}{l}\text { II9,48 } \\
(28,22)\end{array}$ & $\begin{array}{c}83,32 \\
(4,9)\end{array}$ \\
\hline
\end{tabular}

Izvor: izračun autorica.

Jedinice regionalne samouprave razvrstavaju se prema indeksu razvijenosti u četiri skupine. U tablici 2 za JRS-e dane su granične vrijednosti indeksa razvijenosti po skupinama, broj JRS-a kategoriziranih $\mathrm{u}$ pojedinu skupinu $(N)$, prosječne vrijednosti pokazatelja $X_{\mathrm{I}}, . ., X_{5}$ i standardne devijacije koje su zapisane u zagradama.

Status potpomognutog područja stječu JRS-i razvrstani u prvu skupinu, te JLS-i razvrstani u prvu ili drugu skupinu. U Hrvatskoj postoji 556 JLS-a i to 429 općina i I27 gradova te 2I JRS, odnosno županija, pri čemu Grad Zagreb kao glavni grad ima poseban status grada i županije. Od toga se više od trećine 
JLS-a nalazi na području PPDS-a. Na temelju indeksa razvijenosti u područjima koja zaostaju u razvoju kategorizirano je skoro polovica JLS-a i više od polovice JRS-a.

\section{TABLICA 2.}

Kategorizacija JRS-a prema indeksu razvijenosti

\begin{tabular}{|c|c|c|c|c|c|c|c|}
\hline Skupina & Vrijednost indeksa (\%) & $N$ & $X_{1}$ & $X_{2}$ & $X_{3}(\%)$ & $X_{4}$ & $X_{5}(\%)$ \\
\hline I & $<75$ & I2 & $\begin{array}{l}22.798 \\
(2.494)\end{array}$ & $\begin{array}{l}\text { I.9I2 } \\
(472)\end{array}$ & $\begin{array}{l}20,47 \\
(4,78)\end{array}$ & $\begin{array}{c}94, I \\
(2,67)\end{array}$ & $\begin{array}{l}69,38 \\
(3,93)\end{array}$ \\
\hline II & $\langle 75$, IOO $\rangle$ & 3 & $\begin{array}{c}25.460 \\
(785)\end{array}$ & $\begin{array}{l}2.597 \\
(506)\end{array}$ & $\begin{array}{l}16,43 \\
(3,58)\end{array}$ & $\begin{array}{l}\text { IOO,3 } \\
(3,57)\end{array}$ & $\begin{array}{l}78,84 \\
(4,32)\end{array}$ \\
\hline III & $\langle\mathrm{IOO}, \mathrm{I} 25\rangle$ & 3 & $\begin{array}{l}27.156 \\
(2.746)\end{array}$ & $\begin{array}{l}3.166 \\
(337)\end{array}$ & $\begin{array}{l}\mathrm{I} 3,20 \\
(\mathrm{I}, 95)\end{array}$ & $\begin{array}{c}\text { IO6,53 } \\
(2,55)\end{array}$ & $\begin{array}{l}79,5 \mathrm{I} \\
(3,7 \mathrm{I})\end{array}$ \\
\hline IV & $>\mathrm{I} 25$ & 3 & $\begin{array}{l}35.662 \\
(5.655)\end{array}$ & $\begin{array}{l}5.213 \\
(682)\end{array}$ & $\begin{array}{l}\text { IO,37 } \\
(2,46)\end{array}$ & $\begin{array}{c}\text { IOI,77 } \\
(2,4)\end{array}$ & $\begin{array}{l}84,23 \\
(3,14)\end{array}$ \\
\hline
\end{tabular}

Izvor: izračun autorica.

\section{METODOLOŠKI ASPEKTI KONSTRUIRANJA KOMPOZITNIH INDEKSA}

U literaturi postoji temeljna podjela između stručnjaka koji podržavaju agregiranje varijabli u kompozitni indeks i onih koji se tome protive. Pobornici agregiranja ističu kako je kompozitnim indeksima moguće jednostavno prikazati stvarno stanje te kako su posebno korisni za privlačenje pažnje javnosti, a time i pažnje donositelja odluka. S druge strane, protivnici agregacije upozoravaju na problematičnost arbitrarnosti u procesu ponderiranja (Sharpe, 2004.). Postoje nesuglasice oko pitanja biranja indikatora i metoda mjerenja dispariteta. Oslanjanje samo na ekonomske pokazatelje je upitno budući da je činjenica da ekonomski razvoj ostavlja za sobom, ili u nekim slučajevima čak i stvara velika područja siromaštva, stagnacije, marginalizacije i stvarnog isključenja iz ekonomskog i socijalnog napretka preočita i prevažna da bi bila zanemarena (United Nations, 1969.). Potreba za uključivanjem većeg broja pokazatelja za mjerenje socio-ekonomskoj razvoja dovela je danas do pozamašnog broja kompozitnih indeksa.

Glavne prednosti kompozitnih indeksa su sposobnost sažimanja kompleksnih ili višedimenzionalnih pojava, jednostavna i direktna interpretacija, privlačenje pozornosti javnosti i reduciranje velikog broja različitih pokazatelja bez gubitka informacija, dok su nedostaci uglavnom vezani uz problem odašiljanja krivih signala ako su indeksi loše konstruirani (Nardo et al., 2005.). Također, kao nedostatak navodi se i direktnost kompozitnih indeksa koja može potaknuti donositelje odluka na donošenje jednostranih zaključaka, a arbitrarni odabir pokazatelja i pondera može dovesti do političkih prepirki i time politiku upravljanja navesti na krivi smjer. Ako je konstrukcija indeksa netransparentna i bez potpore statističkih metoda i konceptualnih principa, vrijednostima indeksa može se manipulirati kako bi se dala potpora željenoj politici. Osnovni koraci konstrukcije kompozitnih indeksa su konstrukcija teorijskog okvira, odabir podataka, nadomještanje nedostupnih podataka, multivarijatna analiza, normalizacija, ponderiranje, agregiranje, analiza neizvjesnosti i osjetljivosti, povezivanje s drugim pokazateljima te vizualizacija (Nardo et al., 2005.).

\section{I. ODABIR POKAZATELJA}

Snage i slabosti kompozitnih indeksa izviru iz kvalitete pokazatelja uključenih u izračun. Odabir pokazatelja treba biti temeljen na analitičkoj ispravnosti, mjerljivosti, dostupnosti i važnosti pokazatelja za fenomen koji se mjeri te na međusobnom odnosu pokazatelja. Proces odabira podataka trebao bi pratiti unaprijed određen teoretski okvir čime se ograničava subjektivnost istraživača. 
Također, primjenom multivarijatne analize, koja se bazira isključivo na podacima, moguće je zaobići subjektivne odluke istraživača. Provođenje multivarijatne analize omogućuje utvrđivanje strukture podataka te pomaže u rukovođenju metodologijom konstrukcije kompozitnih indeksa. Multivarijatne metode omogućuju ispitivanje prisutnosti multikolinearnosti pokazatelja. Multikolinearnost uzrokuje nejednak položaj varijabli budući da kolinearne varijable mjere isti fenomen koji tada ima višestruk doprinos vrijednosti kompozitnog indeksa. Dodatni je problem što pojava multikolinearnosti otežava interpretaciju jer je teško utvrditi utjecaj pojedine varijable. Ako su dvije varijable visoko korelirane, suvišno je obje uključivati u dani model (Salzman, 2003.).

Pri kreiranju novog kompozitnog indikatora, indeksa razvijenosti, osnovni kriterij za odabir pokazatelja bila je procjena njegovog doprinosa stvaranju što objektivnije slike o socio-ekonomskim razlikama među jedinicama, te su pritom pokazatelji kao što su dohodak per capita te stopa nezaposlenosti postali ključni pokazatelji socio-ekonomskih razlika, dok je dio pokazatelja isključen na temelju njihove slabe vjerodostojnosti, previsoke korelacije pojedinih pokazatelja te preniske korelacije pojedinih pokazatelja s ključnim ekonomskim pokazateljima (Puljiz et al., 2005.). Tako su primjerice infrastrukturni pokazatelji ocijenjeni kao nevjerodostojni, pokazatelji udio osoba koji ostvaruju prihode u cijeloj populaciji i dohodak per capita imaju previsok stupanj korelacije od o,93, a vitalni indeks i indeks starenja isključeni su zbog preniske koreliranosti s pokazateljima dohodak per capita i stopa nezaposlenosti (Puljiz, 2007.). Zbog određenih poteškoća u metodologiji izračuna, BDP per capita nije bio uključen u razvoj indeksa razvijenosti, no kako je očekivan rast pouzdanosti procjene BDP-a kao pokazatelja i dalje se razmatra kao potencijalni pokazatelj (Puljiz, 2007.). Potrebno je napomenuti kako BDP per capita nije moguće koristiti na lokalnoj razini, budući se njegov izračun vrši na državnoj i županijskoj razini. Uredbom o indeksu razvijenosti propisani su pokazatelji korišteni u izračunu indeksa: dohodak per capita, izvorni prihodi JLS-a odnosno JRS per capita, stopa nezaposlenosti, kretanje stanovništva i stopa obrazovanosti (Uredba o indeksu razvijenosti, 20Io). Vrijednosti pokazatelja preuzete su od MRRFEU (MRRFEU, 20I3a., 20I3b., 20IOa., 2OIob.). Dohodak per capita izračunava se kao omjer ukupnog iznosa dohotka kojega su tijekom jednoga poreznog razdoblja (kalendarska godina) ostvarili porezni obveznici, fizičke osobe s prebivalištem ili uobičajenim boravištem na području jedinice lokalne, odnosno područne (regionalne) samouprave za koju se vrši izračun, i broja stanovnika koji žive na području te jedinice. Proračunski prihodi jedinica lokalne, odnosno područne (regionalne) samouprave per capita izračunavaju se kao omjer ostvarenih prihoda jedinica lokalne, odnosno područne (regionalne) samouprave, umanjenih za prihode: od domaćih i stranih pomoći i donacija, iz posebnih ugovora: sufinanciranje građana za mjesnu samoupravu, ostvarene na osnovi dodatnih udjela u porezu na dohodak i pomoći za izravnanja za financiranje decentraliziranih funkcija i od prireza porezu na dohodak, prihode od prodaje nefinancijske imovine i broja stanovnika na području jedinice lokalne odnosno područne (regionalne) samouprave. Stopa nezaposlenosti izračunava se kao omjer broja nezaposlenih i zbroja svih zaposlenih te nezaposlenih osoba na području pojedine jedinice lokalne odnosno područne (regionalne) samouprave. Opće kretanje stanovništva izračunava se kao omjer usporedivog broja stanovnika jedinica lokalne, odnosno područne (regionalne) samouprave u dva zadnja popisa stanovništva. Stopa obrazovanosti izračunava se kao udjel stanovništva sa završenom srednjom školom i višom razinom obrazovanosti u ukupnom stanovništvu, u dobi između I6 i 65 godina, na području jedinice lokalne, odnosno područne (regionalne) samouprave. 
U tablicama 3 i 4 dani su sljedeći parametri analiziranih podataka JLS-a odnosno JRS-a: najmanja vrijednost $(\mathrm{min})$, najveća vrijednost $(\max )$, prosječna vrijednost $(\bar{x})$, standardna devijacija $(\sigma) \mathrm{i}$ koeficijent asimetrije (skew). Najveća disperzija može se uočiti kod pokazatelja $X_{2}$ i na JLS i JRS razini.

\section{TABLICA 3.}

Pokazatelji JLS-a

\begin{tabular}{|c|c|c|c|c|c|}
\hline Pokazatelj & Min. & Max. & $\bar{x}$ & $\sigma$ & skew \\
\hline $\mathrm{X}_{1}$ & 7.105 & 42.175 & 2I.6o9,I4 & $6.088,6$ & 0,38 \\
\hline $\mathrm{X}_{2}$ & 223 & IO.II5 & I9.8I,59 & I.695,36 & I,96 \\
\hline $\mathrm{X}_{3}(\%)$ & 4,5 & 54,48 & I8,94 & 9,24 & 0,86 \\
\hline $\mathrm{X}_{4}$ & $4 \mathrm{I}, 3$ & 247,8 & 98,3 & I3, 8 & $2,72^{a}$ \\
\hline $\mathrm{X}_{5}(\%)$ & 31,65 & $90,4 \mathrm{I}$ & 68,58 & II,O7 & $-0,36$ \\
\hline
\end{tabular}

a Posljedica izdvojenice, isključivanjem izdvojenice je koeficijent zaobljenosti o,65.

Izvor: izračun autorica.

\section{TABLICA 4.}

Pokazatelji JRS-a

\begin{tabular}{|c|c|c|c|c|c|}
\hline Pokazatelj & Min. & Max. & $\bar{x}$ & $\sigma$ & skew \\
\hline $\mathrm{X}_{1}$ & I9.455 & 42.175 & $25.638,19$ & $5.262,95$ & I,66 \\
\hline $\mathrm{X}_{2}$ & I.368 & 5.997 & $2.660,48$ & I. 248,45 & I,36 \\
\hline $\mathrm{X}_{3}(\%)$ & 7,80 & 25,90 & $\mathrm{I} 7,4 \mathrm{I}$ & 5,54 & $\mathrm{O}, \mathrm{I7}$ \\
\hline $\mathrm{X}_{4}$ & 90,7 & IO9,I & 97,86 & 5,42 & 0,50 \\
\hline $\mathrm{X}_{5}(\%)$ & 62,49 & 86,93 & 74,30 & $7, \mathrm{OI}$ & O,I5 \\
\hline
\end{tabular}

Izvor: izračun autorica.

\subsection{NORMALIZAGIJA POKAZATELJA}

Zbog različitih mjernih jedinica pokazatelja te postojanja razlika u srednjim vrijednostima i devijaciji, pokazatelje je često nužno normalizirati. Normalizacija može imati presudan učinak na vrijednost kompozitnog indeksa, a time i na rangiranje jedinica. Rangiranje je najjednostavnija metoda koja nije pogođena prisustvom izdvojenica, standardizacija svođenjem na z-vrijednosti jedna je od najpopularnijih metoda normalizacije koja pokazateljima s ekstremnim vrijednostima daje veći utjecaj na kompozitni indeks, min-max metoda normalizira pokazatelje na jednaki raspon, dok referentna normalizacija promatra vrijednost pokazatelja obzirom na neku unaprijed određenu veličinu (prosječna, najmanja, najveća ili neka druga vrijednost određena odlukom stručnjaka).

\section{TABLICA 5.}

Odabrane metode normalizacije

Metoda normalizacije

Standardizacija (z-vrijednosti)

Min-max
Izračun normalizirane vrijednosti pokazatelja

$$
\begin{gathered}
x_{c i}^{*}=\frac{x_{c i}-\bar{x}_{i}}{\sigma_{i}} \\
x_{c i}^{*}=\frac{x_{c i}-x_{i, \min }}{x_{i, \max }-x_{i, \min }}
\end{gathered}
$$$$
x_{c i}^{*}=\frac{x_{c i}}{x_{i}^{0}}
$$ 
Uredbom o indeksu razvijenosti određeno je provođenje normalizacije pokazatelja $X_{i}$ pomoću minmax metode pri čemu se umjesto početne vrijednosti pokazatelja promatra njegova udaljenost od najmanje vrijednosti u uzorku relativno na raspon vrijednosti pokazatelja (formula 5). Nadalje, normalizirana vrijednost svakog pokazatelja dijeli se s normaliziranom vrijednosti pokazatelja na razini Hrvatske te se dobiva

$$
\mathrm{x}_{\mathrm{i}}^{*}=\frac{\frac{x_{i}-x_{i, \min }}{x_{i, \max }-x_{i, \min }}}{\frac{x_{i, H R}-x_{i, \min }}{x_{i, \max }-x_{i, \min }}}=\frac{x_{i}-x_{i, \min }}{x_{i, H R}-x_{i, \min }} .
$$

Kako krajnje vrijednosti pokazatelja najčešće pripadaju izdvojenicama, valjalo bi preispitati ovakav način normalizacije, odnosno razmotriti mogućnost isključivanja izdvojenica ili promjene same metode. Promjena $u$ najmanjoj vrijednosti pokazatelja jedne jedinice može utjecati na konačne vrijednosti indeksa razvijenosti svih ostalih jedinica. Normalizacijom opisanom formulom 5 vrijednost svakog pokazatelja jedinice zapravo se svodi na usporedbu udaljenosti od najmanje vrijednosti pokazatelja u odnosu na nacionalni prosjek.

\subsection{ODABIR PONDERA I METODE AGREGAGIJE}

Možda najteži aspekt konstruiranja višedimenzionalnog indeksa je odabir pondera pokazatelja (Tofallis, 20I3.). Postoji velik broj metoda za određivanje veličine pondera; neke su bazirane na statističkim metodama kao na primjer faktorska analiza, analiza glavnih komponenata (AGK), analiza omeđivanja podataka, dok su druge vezane uz participatorne metode kao što su analitički hijerarhijski proces, proces alokacije budžeta ili conjoint analiza koje uključuju veći broj dionika (stručnjake, građane i političare) (Nardo et al., 2008.). Ponderi su pokazateljima često dodijeljeni uvažavanjem mišljenja stručnjaka vezano uz važnost samog pokazatelja za mjereni fenomen. Takav pristup kritiziran je kao suviše arbitraran budući da odabir pondera može imati značajan utjecaj na veličinu indeksa i rangiranje jedinica. S druge strane, pomoću multivarijatnih metoda moguće je donijeti odluku o ponderima isključivo na temelju podataka i kao takav predstavlja empirijski i relativno objektivniji pristup odabiru. Također, često se problem određivanja pondera zaobilazi dodjeljivanjem jednakih pondera svim pokazateljima čime se implicira jednaka važnost svih pokazatelja, ali i prikriva izostanak statističkih i empirijskih temelja, nedovoljno znanje o uzročnoj vezi varijabli ili nedostatak konsenzusa oko alternativnih pondera (Booysen, 2002.). Kada postoji više visoko koreliranih pokazatelja, dodjeljivanjem jednakih pondera moguće je istom fenomenu dodijeliti višestruku težinu. Stoga je poželjno ispitati koreliranost pokazatelja prije odabira pondera i uzeti u obzir koeficijente korelacije.

Kako a priori determinacija pondera implicira postojanje opće prihvaćene funkcije ljudskog boljitka, odnosno razvoja (Noorbakhsh, 1998.), kao alternativni način može se razmotriti empirijski odabir pondera. U svrhu empirijskog određivanja pondera pojedinog pokazatelja u izračunu indeksa razvijenosti provedena je analiza glavnih komponenata (AGK) za dva izračuna indeksa razvijenosti. AGK omogućuje redukciju originalnih varijabli tako da se umjesto njih koristi manji broj njihovih linearnih kombinacija uz minimiziranje gubitka informacija o varijabilnosti sustava. Bira se $k \leq 5$ linearnih kombinacija $Y_{j}$ varijabli $X_{i}$ koje maksimiziraju varijancu sustava

$$
Y_{j}=\sum_{i=1}^{5} w_{i j} X_{i}, j=1, \ldots, k .
$$

Prva komponenta $Y_{1}$ je linearna kombinacija s najvećom varijancom. Odluku o broju linearnih kombinacija $k$ moguće je donijeti prema više kriterija, na primjer pomoću Kaiserovog kriterija 
(uzimaju se samo one linearne kombinacije čije su svojstvene vrijednosti veće od jedan), a priori kriterija, Catellijevog dijagrama ili postotka objašnjene varijance (Hair et al., I995.). U praksi malen broj indeksa koristi AGK u izboru pondera. Jednim dijelom zato što je teško objasniti proces izračuna nestatističarima, a dijelom zato što se ponderi mijenjaju $\mathrm{s}$ vremenom zajedno s podacima (Foa $\mathrm{i}$ Tanner, 20II.).

Budući da se kompozitnim pokazateljima nastoji prikazati višedimenzionalan sustav pomoću jednodimenzionalnog, potrebno je pronaći odgovarajuću metodu agregacije. Aditivna agregacija najjednostavnija je metoda agregacije i neosjetljiva je na postojanje izdvojenica. Linearna agregacija najraširenija je korištena metoda, gdje se kompozitni indeks dobiva kao ponderirana suma vrijednosti pokazatelja. Linearna agregacija dopušta kompenzaciju među varijablama, to jest zaostajanje u jednoj dimenziji moguće je nadoknaditi iznadprosječnim veličinama u drugoj dimenziji. Geometrijska agregacija donekle zaobilazi ovaj problem i prikladna je u slučajevima kada se želi postići određen nivo nemogućnosti kompenzacije među varijablama.

\subsection{ANALIZA NEIZVJESNOSTI I ANALIZA OSJETLJIVOSTI}

Odsustvo objektivnog odabira pondera i metode agregacije ne dovodi nužno do neispravnosti kompozitnog indeksa, ali uz uvjet transparentnosti cijelog procesa. Kombinacijom analize neizvjesnosti i analize osjetljivosti može se ocijeniti robustnost kompozitnog indeksa i poboljšati njegova transparentnost (Nardo et al., 2008.). Metodološke odluke kao što su tretiranje nedostupnih podataka, odabir pokazatelja, metode normalizacije i agregacije te odabir pondera uvelike utječu na formu kompozitnog indeksa. Analizom neizvjesnosti cilj je odrediti kako se te subjektivne odluke istraživača reflektiraju na pouzdanost modela. Budući da vrijednost razine razvijenosti teritorijalne jedinice nije moguće egzaktno izmjeriti, nije moguće niti direktno odrediti u kojoj mjeri indeks razvijenosti opisuje tu razinu. Ali kao veličinu mjere razvijenosti kompozitni indeks potrebno je validirati, stoga je pri svakoj njegovoj konstrukciji nužno provesti analizu neizvjesnosti i osjetljivosti. Općenito, neizvjesnosti u razvoju kompozitnog indikatora povezane su s većim brojem faktora uključenih $u$ proces modeliranja: postojanje grešaka u mjerenjima vrijednosti pokazatelja, odabir mehanizma za uključivanje odnosno isključivanje pokazatelja, transformacija pokazatelja, količina nedostupnih podataka, odabir metoda normalizacije, agregacije i posebno odabir pondera (Nardo et al., 2005.). Neizvjesnost indeksa moguće je ispitati proučavanjem glavnih izvora nesigurnosti s ciljem obuhvaćanja mogućih sinergijskih efekata ulaznih parametara (Nardo et al., 2008.), direktno ili putem Monte Carlo simulacija.

Velika osjetljivost kompozitnog indeksa na male promjene $\mathrm{u}$ ulaznim informacijama čini ga nestabilnim i nepouzdanim, stoga je pri kreiranju indeksa nužno odrediti u kojoj mjeri varijacija pojedinog pokazatelja utječe na promjene vrijednosti indeksa. U tu svrhu koriste se metode koje se ne baziraju na određenim pretpostavkama modela (Satelli et al., 2008.), kao što su procedure bazirane na varijanci. Za dani kompozitni indeks $Y$ i pokazatelje $X_{\mathrm{I}}, \ldots, X_{k}$ indeks osjetljivosti prvog stupnja procjenjuje se kao doprinos svakog pokazatelja $X_{i}$ ukupnoj varijanci modela $V(Y)$,

$$
S_{i}=\frac{V_{i}}{V(Y)}
$$

gdje je

$$
V_{i}=V_{X_{i}}\left[E_{X_{-i}}\left(Y \mid X_{i}\right)\right]
$$


varijanca indeksa $Y$ uzrokovana nesigurnošću pokazatelja $X_{i}$. Fiksira se pokazatelj $X_{i}$ dodjelom fiksne vrijednost $x_{i}^{0}$ iz njegovog raspona te se odredi srednja vrijednost indeksa obzirom na sve pokazatelje $\operatorname{osim} X_{i}, E_{X_{-i}}\left(Y \mid X_{i}=x_{i}^{0}\right)$.

Potom se odredi uzoračka varijanca srednjih vrijednosti po svim realizacijama $x_{i}^{0}$ varijable $X_{i}$. Veće vrijednosti indeksa osjetljivosti $S_{i}$ ukazuju na veću ovisnost indeksa $Y$ o varijabilnosti pokazatelja $X_{i}$.

Analogno je moguće procijeniti uvjetnu varijancu indeksa obzirom na dva ili više pokazatelja odjednom (tzv. interakcije) te odrediti indekse osjetljivosti višeg stupnja. U aditivnim modelima (modelima bez interakcija) udio pojedinog pokazatelja $u$ varijanci indeksa $u$ potpunosti je opisan indeksom osjetljivosti prvog stupnja i vrijedi

$$
\sum_{i=1}^{k} S_{i}=1 .
$$

$S_{i}$ je dobra bezmodelska mjera osjetljivosti koja uvijek opisuje očekivano smanjenje varijance outputa koja se dobiva fiksiranjem vrijednosti jednog indikatora (Saltelli et al., 2004.). Općenito, vrijedi

$$
\sum_{i=1}^{k} S_{i} \leq 1 .
$$

U neaditivnim modelima umjesto niza indeksa osjetljivosti višeg stupnja promatra se ukupni efekt svakog pokazatelja $S_{T_{i}}$ koji je određen njihovim zbrojem, odnosno

$$
S_{T_{i}}=S_{i}+\sum_{j=1}^{k} S_{i j}+\sum_{j<k} S_{i j k}+\cdots+S_{1 \ldots k}=\frac{V(Y)-V_{X_{-i}}\left[E_{X_{i}}\left(Y \mid X_{-i}\right)\right]}{V(Y)},
$$

gdje je $V_{X_{-i}}\left[E_{X_{i}}\left(Y \mid X_{-i}\right)\right]$ varijanca indeksa $Y$ uzrokovana nesigurnošću svih pokazatelja osim $X_{i}$. Jednako kao indeks osjetljivosti prvog stupnja, velike vrijednosti ukupnog efekta $S_{T_{i}}$ ukazuju na veću ovisnost indeksa $Y$ o varijabilnosti pokazatelja $X_{i}$, ali uzevši u obzir moguće interakcije s ostalim pokazateljima. Stoga je usporedbom parova $\left(S_{i}, S_{T_{i}}\right)$ moguće odrediti i intenzitet interakcija pokazatelja.

\section{REZULTATII ISTRAŽIVANJA}

\section{I. ISPITIVANJE PRISUTNOSTI MULTIKOLINEARNOSTI I POSTOJANJA IZDVOJENICA}

U tablicama 6 i 7 dane su korelacijske matrice pokazatelja i indeksa razvijenosti na razini JRS-a i JLS-a. Korelacija je visoka i značajna za sve pokazatelje (na razini značajnosti od I\%). Problematični (u smislu previsokog stupnja koreliranosti) koeficijenti korelacije na razini JRS-a posebno su izraženi kod pokazatelja prosječni izvorni prihodi per capita i dohodak per capita te prosječni izvorni prihodi per capita i stupanj obrazovanosti stanovništva.

\section{TABLICA 6.}

Korelacijska matrica JRS-a

\begin{tabular}{cccccc} 
& $\mathbf{X}_{\mathbf{I}}$ & $\mathbf{X}_{\mathbf{2}}$ & $\mathbf{X}_{3}$ & $\mathbf{X}_{\mathbf{4}}$ & $\mathbf{X}_{5}$ \\
\hline$X_{\mathrm{I}}$ & $\mathrm{I}$ & & & & \\
\hline$X_{2}$ & 0,92 & $\mathrm{I}$ & & & \\
\hline$X_{3}$ & $-0,68$ & $-0,67$ & $\mathrm{I}$ & & \\
\hline$X_{4}$ & 0,44 & 0,55 & $-0,59$ & $\mathrm{I}$ & \\
\hdashline$X_{5}$ & 0,79 & $0,8 \mathrm{I}$ & $-0,57$ & 0,66 & $\mathrm{I}$ \\
\hline
\end{tabular}

Izvor: izračun autorica.
TABLICA 7.

Korelacijska matrica JLS-a

\begin{tabular}{cccccc} 
& $\mathbf{X}_{\mathbf{I}}$ & $\mathbf{X}_{\mathbf{2}}$ & $\mathbf{X}_{3}$ & $\mathbf{X}_{4}$ & $\boldsymbol{X}_{5}$ \\
\hdashline$X_{\mathrm{I}}$ & $\mathrm{I}$ & & & & \\
\hdashline$X_{2}$ & $0,5 \mathrm{I}$ & $\mathrm{I}$ & & & \\
\hdashline$X_{3}$ & $-0,67$ & $-0,48$ & $\mathrm{I}$ & & \\
\hdashline$X_{4}$ & 0,25 & $0,5 \mathrm{I}$ & $-0,39$ & $\mathrm{I}$ & \\
\hdashline$X_{5}$ & 0,73 & 0,55 & $-0,55$ & $0,5 \mathrm{I}$ & $\mathrm{I}$ \\
\hline
\end{tabular}


Postojanje multikolinearnosti ispitano je pomoću faktora inflacije varijance i kondicionog indeksa. Kako su zabilježene vrijednosti faktora inflacije varijance veće od 7 te je vrijednost kondicionog indeksa 13,8, može se zaključiti kako je u modelu prisutna multikolinearnost varijabli (Bahovec i Erjavec, 2009.; Gujarati, 2004.). Taj je problem moguće zaobići izostavljanjem određenog pokazatelja, odnosno njegovom zamjenom drugim pokazateljem. Na primjer, problem multikolinearnosti zabilježen kod indeksa razvijenosti za razdoblje 2006.-2008. riješen je izostavljanjem pokazatelja izvorni prihodi per capita odnosno zamjenom alternativnim pokazateljima snage županijskih proračuna (Perišić, 20I4.). Visok stupanj koreliranosti pokazatelja dohodak per capita i prosječni izvorni prihodi per capita je očekivan budući da se prihodi lokalnih proračuna uglavnom oslanjaju na prihode od poreza na dohodak. Naime, u financiranju lokalnih jedinica ključno je financiranje porezima i to prije svega porezom na dohodak i prirezom poreza na dohodak (Ott, 2009.). Stoga je upitno istovremeno korištenje pokazatelja dohodak per capita i prosječni izvorni prihodi per capita budući da je na županijskoj razini dostupan najznačajniji pokazatelj gospodarske aktivnosti, BDP per capita. Kao alternativni pokazatelj financijske snage i neovisnosti lokalnih proračuna moguće je koristiti udio izvornih prihoda u ukupnim prihodima lokalne jedinice.

Postojanje izdvojenica ispitano je pomoću Mahalanobisove udaljenosti, podaci s velikim vrijednostima ocijenjeni su kao izdvojenice (Ben Gal, 2005.). Na grafikonu I prikazane su kvadratne Mahalanobisove udaljenosti JLS-a za razdoblje 2006.-2008. i 20I0.-2012.

\section{GRAFIKON I.}

Analiza izdvojenica

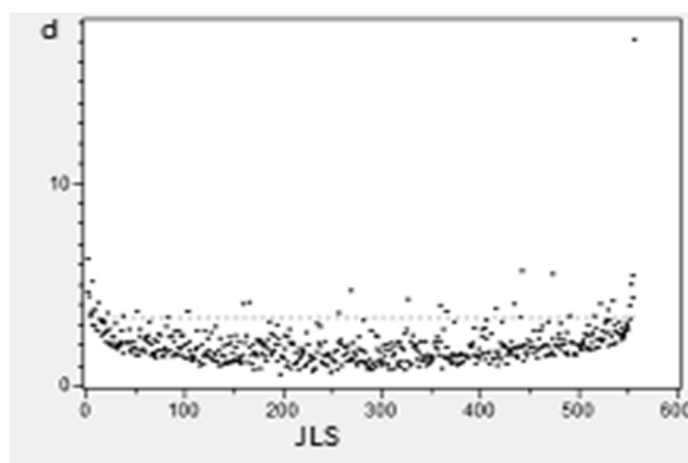

Razdoblje 2006.-2008.

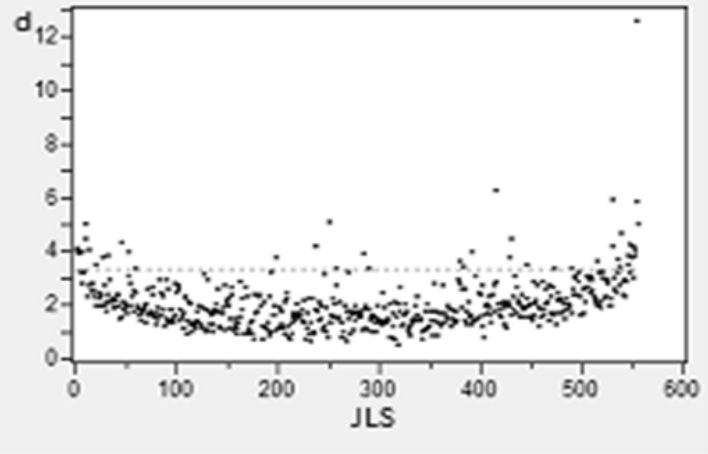

Razdoblje 2OIO.-20I2.

Izvor: izračun autorica.

U izračunima za oba razdoblja u gornjem desnom kutu grafikona ističe se izdvojenica. U prvom slučaju radi se o općini Dugopolje za razdoblje 2006.-2008. koja se ističe ekstremno visokom prosječnom vrijednosti izvornih prihoda per capita. Usporedbe radi, JLS koja je slijedi po veličini izvornih prihoda per capita i veličini indeksa razvijenosti je općina Kostrena s više od tri puta manjim izvornim prihodima per capita. Također, općina Dugopolje ima čak dvadeset puta veće izvorne prihode per capita od prosjeka ostalih JLS-a. Upravo primjer općine Dugopolje ukazuje na problem rangiranja jedinica ponderiranjem prosječnih vrijednosti više pokazatelja, budući da je zaostajanje u jednoj dimenziji moguće nadoknaditi u drugim dimenzijama i dati lažnu sliku o razini socioekonomske razvijenosti jedinice. Ekstremno visoki prosječni izvorni prihodi per capita općine Dugopolje rezultat su kratkoročnog izvora financiranja kao što je prodaja zemljišta. Slična situacija zabilježena je i kod drugih jedinica. Za razdoblje 20Io.-20I2. kao izdvojenica ističe se općina Vir koja 
bilježi ekstremno velike vrijednosti pokazatelja kretanje stanovništva od čak 247,8 . Osim što stvaraju lažnu sliku u ocjeni razvijenosti same jedinice, izdvojenice utječu i na izračun indeksa razvijenosti ostalih jedinica. Taj utjecaj, kao i utjecaj različitih raspona vrijednosti pokazatelja, nastoji se ukloniti transformacijom i normalizacijom podataka.

\subsection{REZULTATI ANALIZE GLAVNIH KOMPONENATA}

Analiza glavnih komponenata provedena je za dva izračuna indeksa razvijenosti JLS-a i JRS-a. A priori je odabrana samo jedna linearna kombinacija $(k=1)$ koja predstavlja alternativu indeksu razvijenosti. Budući da samo jedna linearna kombinacija bilježi svojstvenu vrijednost veću od I, što udovoljava Kaiserovom kriteriju, statistički je opravdan odabir samo jedne komponente. Metodom AGK-a izračunati su ponderi pokazatelja za JLS-e i JRS-e koji su zatim normirani. Dobiveni ponderi prikazani su u tablici 8. Potrebno je napomenuti kako su prije provođenja AGK-a izdvojenice isključene.

\section{TABLica 8.}

Normirani ponderi pokazatelja JLS-a i JRS-a dobivene AGK-om

\begin{tabular}{|c|c|c|c|c|c|c|}
\hline $\begin{array}{l}\text { Normirani } \\
\text { ponderi } \\
\qquad w^{A G K}\end{array}$ & $\begin{array}{l}\text { Dohodak } \\
w_{1}^{A G K}\end{array}$ & $\begin{array}{c}\text { Izvorni } \\
\text { prihodi } \\
w_{2}^{A G K}\end{array}$ & $\begin{array}{c}\text { Stopa } \\
\text { nezaposlenosti } \\
w_{3}^{A G K}\end{array}$ & $\begin{array}{c}\text { Kretanje } \\
\text { stanovništva } \\
w_{4}^{A G K}\end{array}$ & $\begin{array}{c}\text { Stopa } \\
\text { obrazovanosti } \\
w_{5}^{A G K}\end{array}$ & $\begin{array}{c}\text { Udio } \\
\text { objašnjene } \\
\text { varijance (\%) }\end{array}$ \\
\hline $\begin{array}{l}\text { Indeks JLS-a } \\
\text { 2OIO.-2OI3. }\end{array}$ & $\mathrm{O}, 2 \mathrm{I}$ & 0,20 & 0,20 & O,I7 & 0,22 & 62 \\
\hline $\begin{array}{l}\text { Indeks JLS-a } \\
\text { 2006.-2008. }\end{array}$ & 0,23 & O,I8 & $\mathrm{O}, 2 \mathrm{I}$ & O,I5 & 0,23 & 55 \\
\hline $\begin{array}{l}\text { Indeks JRS-a } \\
\text { 2OIO.-2OI3. }\end{array}$ & $\mathrm{O}, 2 \mathrm{I}$ & 0,22 & O,I9 & $\mathrm{O}, \mathrm{I7}$ & $\mathrm{O}, 2 \mathrm{I}$ & 74 \\
\hline $\begin{array}{l}\text { Indeks JRS-a } \\
\text { 2006.-2008. }\end{array}$ & 0,24 & 0,24 & 0,20 & O,IO & 0,22 & 66 \\
\hline
\end{tabular}

Izvor: izračun autorica.

Pokazatelj kretanje stanovništva najslabije je koreliran s ostalim pokazateljima, pa je i ponder dobiven metodom AGK-a najmanji. Ovo je nedostatak metode AGK budući da pokazateljima koji su najslabije korelirani s ostalim pokazateljima dodjeljuje najmanje pondere. Unatoč tome, ponderi demografskih pokazatelja dobiveni metodom AGK veći su u odnosu na pondere određene Uredbom Vlade i to na lokalnoj i regionalnoj razini.

Prema indeksu izračunatom koristeći pondere dobivene metodom AGK, $I^{A G K}$, ukupno je 57 JLS-a kategorizirano u skupinu I dok je 2II JLS-a kategorizirano u skupinu II. Pri korigiranju indeksa jedinica koje se nalaze na PPDS-u umanjivanjem za Io postotnih bodova druga se skupina proširuje na 239 JLS-a, a samo tri JLS-a koje su prema indeksu razvijenosti kategorizirane u skupine I i II su po indeksu dobivenom iz AGK-a kategorizirane u skupine višeg stupnja razvoja. Na županijskoj razini nema razlike $\mathrm{u}$ kategorizaciji potpomognutih područja temeljem indeksa razvijenosti i indeksa dobivenog metodom AGK-a. Vrijednosti indeksa dobivenog metodom AGK na razini JRS-a dani su u tablici Io. 


\subsection{Alternativna NORMALIZAGiJA}

Indeks razvijenosti $I_{c}$ lokalne jedinice $c$ računa se kao ponderirani prosjek odstupanja normaliziranih vrijednosti odabranih pet pokazatelja od prosjeka države

$$
I_{c}=\sum_{i=1}^{5} w_{i} \frac{x_{c, i}-\mathrm{x}_{i, \min }}{x_{i, H R}-\mathrm{x}_{i, \min }} .
$$

U odjeljku 3.2. kritizirana je metoda normalizacije koja se koristi pri izračunu indeksa razvijenosti. Kada bi se umjesto uprosječivanja vrijednosti pokazatelja promatralo odstupanje indeksa JLS-a ili JRSa u odnosu na referentni indeks države (formula I3), uklonio bi se gubitak utjecaja najveće vrijednosti pokazatelja, te bi sam indeks bio manje osjetljiv na ekstremne vrijednosti pokazatelja. Dakle, indeks razvijenosti odredio bi se kao ponderiran prosjek istih pokazatelja samo na razini države.

$$
I_{C}{ }^{N \prime}=\frac{\sum_{i=1}^{5} w_{i} \frac{x_{c i}-x_{i, \min }}{\bar{x}_{i, \max }-x_{i, \min }}}{\sum_{i=1}^{5} w_{i} \frac{x_{i, H R}-x_{i, \min }}{x_{i, \max } x_{i, \min }}} .
$$

\subsection{ANALIZA NEIZVJESNOSTI INDEKSA RAZVIJENOSTI}

\subsection{ANALIZA NEIZVJESNOSTI INDEKSA JEDINICA LOKALNE SAMOUPRAVE}

Usporedbom indeksa razvijenosti Hrvatske s analognim kompozitnim indeksima zemalja u okruženju kao najveći izvori neizvjesnosti pokazuju se izbor pondera i normalizacija pokazatelja. Ukupno je promatrano I2 modela: 3 normalizacije opisane u tablici 5 i metoda normalizacije određena uredbom Vlade (formula 5); 3 izbora pondera (ponderi određeni uredbom Vlade $w^{V}$, ponderi dobiveni analizom glavnih komponenata za razdoblje 20IO.-20I2. $w^{A G K}$ (tablica 8) i jednaki ponderi $w^{E}=(0,2 ; 0,2 ; 0,2 ; 0,2$; o,2)). Budući da indeksi izračunati različitim metodama normalizacije nisu međusobno usporedivi, neizvjesnost modela promatrana je $\mathrm{u}$ odnosu na vrijednosti pripadnih rangova jedinica. Za svaki model $i=1, \ldots, 12$ određen je indeks razvijenosti $I_{\mathrm{c}}^{i}$ te na temelju njega rangovi $R_{c}^{i}, c=1, \ldots, 556 \mathrm{JLS}$-a. Na grafikonu 2 prikazane su najmanja, najveća i medijalna vrijednost ranga za jedinicu $c$ u odnosu na rang $R_{c}^{N V}$ određen nekorigiranim indeksom razvijenosti $I_{c}^{N V}$.

\section{GRAFIKON 2.}

Analiza neizvjesnosti indeksa JLS-a putem ranga

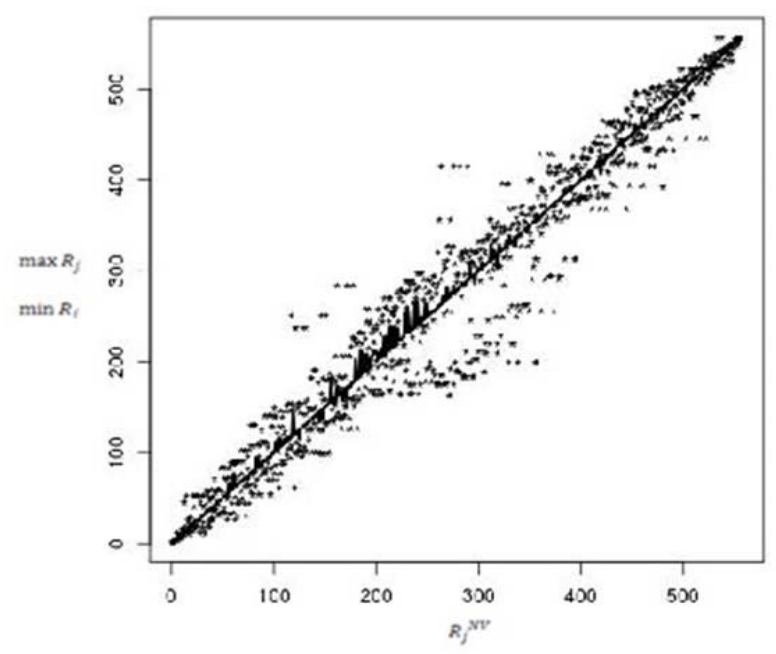

Izvor: izračun autorica.

Skokovi medijalnog ranga prikazani u grafikonu 2 ukazuju na moguće precjenjivanje, odnosno podcjenjivanje razvijenosti određenih JLS-a i to posebno za jedinice srednje i srednje niske razine 
razvijenosti. Na istom skupu jedinica uočen je i širi raspon vrijednosti pokazatelja, što ukazuje na nemogućnost modela da koncizno ocijeni njihovu razvijenost. To ukazuje na značajna odstupanja $u$ kategorizaciji temeljem indeksa razvijenosti definiranog obzirom na kategorizaciju prema ostalim modelima.

Budući da je ključni problem pri kreiranju kompozitnih indeksa određivanje relativne važnosti pokazatelja, a time i pripadnih pondera te da osjetljivost indeksa na promjenu pondera otvara mogućnost manipulacije kategorizacijom jedinica koje zaostaju u razvoju, ispitana je neizvjesnost indeksa obzirom na promjene u odabranim ponderima pokazatelja.

Za svaku JLS $c$ izračunat je minimalni $I_{c}^{\min }$ i maksimalni $I_{c}^{\max }$ mogući indeks pri čemu su ponderi birani iz intervala $[0, \mathrm{I} ; \mathrm{o}, 6]$ i potom normirani.

$$
I_{c}^{\min }=\min _{\substack{w_{i} \in[0.1,0.6] \\ \sum_{i=1}^{5} w_{i}=1}}\left\{\sum_{i=1}^{5} w_{i} x_{c i}\right\} \quad \text { i } \quad I_{c}^{\max }=\max _{\substack{w_{i} \in[0.1,0.6] \\ \sum_{i=1}^{5} w_{i}=1}}\left\{\sum_{i=1}^{5} w_{i} x_{c i}\right\}
$$

Izdvojimo samo kako je u slučaju maksimalnog mogućeg indeksa razvijenosti $I_{c}^{\max }$ čak $56 \%$ jedinica s područja prve i druge skupine svrstano u skupine III, IV ili V, odnosno nisu ocijenjene kao jedinice koje zaostaju u razvoju, dok je u slučaju minimalnog indeksa $I_{c}^{\min }$ više od $43 \%$ jedinica iz skupina III, IV i V kategorizirano u skupine koje zaostaju u razvoju.

Analiza neizvjesnosti indeksa JLS-a obzirom na odabir pondera provedena je pomoću Monte Carlo simulacija. Provedene su tri vrste simulacija s obzirom na odabranu razdiobu pondera:

(a) Prva simulacija $S_{1}$ provedena je generiranjem 2.500 pondera iz uniformne distribucije $w_{i} \sim U(0,25 ; 0,6)$ pri čemu su normiranjem dobiveni ponderi u rasponu od o,I do o,35. Time je isključena mogućnost dominiranja ili marginaliziranja pojedinog pokazatelja.

(b) Druga simulacija $S_{2}$ provedena je generiranjem 2.500 pondera iz uniformne distribucije $w_{i} \sim U\left(\frac{3}{4} w_{i}^{V}, \frac{5}{4} w_{i}^{V}\right), i=1,2, \ldots, 5$, gdje su $w_{i}^{V}$ jednaki vrijednostima pondera pripadnog pokazatelja određenog uredbom Vlade.

(c) Treća simulacija $S_{3}$ provedena je generiranjem 2.500 pondera iz uniformne distribucije $w_{i} \sim U\left(\frac{3}{4} w_{i}^{A G K}, \frac{5}{4} w_{i}^{A G K}\right), i=1,2, \ldots, 5$ gdje su $w_{i}^{A G K}$ jednaki vrijednostima pondera pripadnog pokazatelja dobivenih AGK-om.

Svi su ponderi nakon simulacija normirani te je za svaku od tri vrste simulacija i za svaku JLS $c$ izračunato 500 vrijednosti indeksa razvijenosti $I_{c, k}, k=1,2, \ldots, 500$. Prva simulacija daje najveću slobodu u generiranju pondera, dok druga i treća razdioba generiraju pondere oko pondera određenih uredbom Vlade $w^{V}$ odnosno pondera $w^{A G K}$ dobivenih metodom AGK.

U tablici 9 dan je postotak zadržavanja kategorizirane skupine dodijeljene prema indeksu razvijenosti $I^{N V}$ te prosječan raspon simuliranih indeksa $\overline{\mathrm{I}}_{\max -\min }=\frac{1}{556} \sum_{k=1}^{556}\left(I_{c}^{\max }-I_{c}^{\min }\right)$ gdje je $I_{c}^{\max }=\max _{k=1, \ldots 500} I_{c, k}$ i $I_{c}^{\min }=\min _{k=1, \ldots, 500} I_{c, k}$ redom najveća i najmanja vrijednost indeksa u svakoj simulaciji. Također u tablici 9 je dana frekvencija pogrešno kategoriziranih JLS $\left(n_{w}\right)$ za koje je vjerojatnost pogrešne kategorizacije $p_{w}(c)$ veća od 0,45 ,

$$
n_{w}=\sum_{c=1}^{556} 1_{p_{w}(c)>0,45} .
$$

Vjerojatnost pogrešne kategorizacije određena je relativnom frekvencijom pogrešnih kategorizacija JLS-a u odnosu na kategorizaciju prema $I_{c}^{N V}$ za simulacije redom $S_{\mathrm{I}}$ i $S_{2}$, odnosno na kategorizaciju prema $I_{c}^{A G K}$ za simulacije $S_{I}$ i $S_{3}$. 


\section{TABLICA 9.}

Rezultati simulacija pondera na razini JLS-a

\begin{tabular}{|c|c|c|c|c|c|c|c|}
\hline \multirow{2}{*}{ Simulacija pondera } & \multicolumn{5}{|c|}{ Zadržavanja u skupini (\%) } & \multirow{2}{*}{$\mathrm{n}_{\mathrm{w}}$} & \multirow{2}{*}{$\bar{I}_{\text {max }-\min }$} \\
\hline & I & II & III & IV & $\mathrm{V}$ & & \\
\hline$S_{\mathrm{I}} \quad w_{i} \sim U(0.25,0.6)$ & 87 & 92 & 80 & 82 & 98 & $\begin{array}{l}7 \mathrm{I}^{\mathrm{a}} \\
3 \mathrm{I}^{\mathrm{b}}\end{array}$ & O,I4 \\
\hline$S_{2} \quad w_{i} \sim U\left(\frac{3}{4} w_{i}^{V}, \frac{5}{4} w_{i}^{V}\right)$ & 96 & 94 & 94 & 96 & 96 & 9 & 0,08 \\
\hline$S_{3} \quad w_{i} \sim U\left(\frac{3}{4} w_{i}^{A G K}, \frac{5}{4} w_{i}^{A G K}\right)$ & 96 & 94 & 94 & 95 & 98 & 6 & o,o8 \\
\hline
\end{tabular}

ä Broj pogrešno kategoriziranih prema $I^{N V}$.

${ }^{b}$ Broj pogrešno kategoriziranih prema $I^{A G K}$.

Izvor: izračun autorica.

Broj pogrešno kategoriziranih JLS-a obzirom na kategorizaciju određenu $I^{A G K}$ u simulaciji $S_{I}$ koja dopušta najveću slobodu odabiru pondera iznosi 3I, što je značajno manje od broja pogrešnih kategorizacija obzirom na kategorizaciju temeljem indeksa razvijenosti $I^{N V}$ (ukupno 7I). Može se zaključiti da je kategorizacija temeljem indeksa razvijenosti $I^{N V}$ manje pouzdana u odnosu na AGK kategorizaciju. Također, promatramo li manje perturbacije pondera oko $w^{V}$ odnosno $w^{A G K}$ može se uočiti veća pouzdanost kategorizacije temeljene na indeksu AGK.

Korištenje Monte Carlo simulacija otvara mogućnost korištenja intervalnih procjena u svrhu procjene razine razvijenosti JLS-a. Također, primjenom simulacija moguće je i procijeniti vjerojatnost pogrešne kategorizacije za svaku teritorijalnu jedinicu, što je posebno korisno u slučaju rubnih teritorijalnih jedinica. Primjerice, općina Lećevica s indeksom razvijenosti 75,36\% nije kategorizirana u skupinu potpomognutih područja, dok je u $84 \%$ simulacija $S_{\text {I }}$ kategorizirana u potpomognutu skupinu. Slična situacija je zabilježena kod više od 20 JLS-a (u prilogu). Zbog velikog broja JLS-a, intervalne procjene prikazane su samo na razini JRS-a u tablici Io.

\subsubsection{ANALIZA NEIZVJESNOSTI INDEKSA JEDINICA REGIONALNE SAMOUPRAVE}

Metodologija izračuna indeksa razvijenosti na regionalnoj razini jednaka je onoj na lokalnoj. Pitanje je trebaju li nužno te dvije metodologije biti jednake. Posebno, je li odabir istih pondera pokazatelja u indeksu razvijenosti ispravna?

Za svaki JRS $c$ izračunati su indeksi razvijenosti pomoću pondera dobivenih uredbom Vlade $I_{c}^{V} \mathrm{i}$ indeksi razvijenosti pomoću pondera dobivenih analizom glavnih komponenata $I_{c}^{A G K}$. Na temelju indeksa izračunati su pripadni rangovi JRS-a te su podaci dani u tablici Io, pri čemu su pripadni rangovi dani u zagradi.

Analiza neizvjesnosti indeksa JRS-a obzirom na odabir pondera provedena je pomoću Monte Carlo simulacija, analogno kao u slučaju JLS-a generirani su uzorci pondera duljine 5.000 iz uniformnih razdioba. Za svaku simulaciju $S_{j}$ i za svaku JRS $c$ izračunato je I.ooo vrijednosti indeksa razvijenosti $I_{c, k}^{S_{j}}, k=1,2, \ldots 1000, j=1,2,3$. Također su dane intervalne procjene indeksa razvijenosti na razini pouzdanosti 90\% za 2I JRS izračunate na temelju percentilnih vrijednosti indeksa, posebno za svaku simulaciju.

Usporedbom donjih granica intervalnih procjena izračunatih za simulacije $S_{\mathrm{I}}$ i $S_{3}$, može se zaključiti kako je indeksom razvijenosti $I^{V}$ podcijenjena razina razvijenosti Virovitičko-podravske, Brodskoposavske, Vukovarsko-srijemske, Osječko-baranjske i Splitsko-dalmatinske županije. Kod navedenih županija je vrijednost indeksa razvijenosti manja od donje granice intervalnih procjena dobivenih iz 
simulacija $S_{I}$ i $S_{3}$. S druge strane, usporedbom vrijednosti indeksa razvijenosti $I^{V}$ i gornjih granica istih intervala može se zaključiti o mogućem precjenjivanju razine razvijenosti Bjelovarsko-bilogorske, Varaždinske i Koprivničko-križevačke županije budući da je vrijednost indeksa razvijenosti veća od gornje granice intervalnih procjena. Odabir pondera ne utječe značajno na kategorizaciju JRS-a u skupine definirane odlukom Vlade, ali utječe na rang pojedinih županija. Prema indeksu razvijenosti Splitsko-dalmatinska županija kategorizirana je u drugu skupinu, dok bi prema prosječnom simuliranom indeksu i prema indeksu dobivenom iz AGK-a trebala biti kategorizirana u višu skupinu razvijenosti.

\section{TABLIGA IO.}

Usporedba veličine indeksa i pripadnog ranga (dano u zagradi)

\begin{tabular}{|c|c|c|c|c|c|c|}
\hline Županija (c) & $\overline{\mathbf{I}}_{c}^{S_{1}}(\%)$ & $I_{c}^{V}(\%)$ & $I_{c}^{A G K}(\%)$ & $90 \%$ PI za $I_{c}^{S_{1}}$ & $90 \%$ PI za $I_{c}^{S_{2}}$ & $90 \% \mathrm{PI} \mathrm{za} I_{c}^{S_{3}}$ \\
\hline Virovitičko-podravska & 7,I8 (I) & $5,56(\mathrm{I})$ & $7(\mathrm{I})$ & $\langle 0,06 ; 0,08\rangle$ & $\langle 0,05 ; 0,06\rangle$ & $\langle 0,06 ; 0,08\rangle$ \\
\hline Brodsko-posavska & $24,03(4)$ & $\mathrm{I} 8,43(2)$ & $22,42(4)$ & $<0,19 ; 0,29>$ & $\langle\mathrm{O}, \mathrm{I} 6 ; \mathrm{O}, 2 \mathrm{I}\rangle$ & $\langle 0,2 \mathrm{O} ; \mathrm{O}, 25\rangle$ \\
\hline Vukovarsko-srijemska & $22,65(3)$ & $\mathrm{I} 8,73(3)$ & $2 I, 74(2)$ & $\langle 0,19 ; 0,26\rangle$ & $\langle 0, I 7 ; 0,2 I\rangle$ & $\langle 0,2 \mathrm{O} ; 0,24\rangle$ \\
\hline Bjelovarsko-bilogorska & $21,96(2)$ & $23,29(4)$ & $2 \mathrm{I}, 84(3)$ & $\langle 0,2 \mathrm{I} ; \mathrm{O}, 23\rangle$ & $\langle 0,23 ; 0,24\rangle$ & $\langle\mathrm{O}, 2 \mathrm{I} ; \mathrm{O}, 22\rangle$ \\
\hline Požeško-slavonska & $30,25(5)$ & $33,8 \mathrm{I}(5)$ & $29, \mathrm{OI}(5)$ & $\langle 0,26 ; 0,34\rangle$ & $\langle 0,31 ; 0,36\rangle$ & $\langle 0,27 ; 0,3 \mathrm{I}\rangle$ \\
\hline Sisačko-moslavačka & $39,75(6)$ & $38,70(6)$ & $4 \mathrm{I}, 54(6)$ & $\langle 0,35 ; 0,44\rangle$ & $\langle 0,36 ; 0,42\rangle$ & $\langle 0,39 ; 0,44\rangle$ \\
\hline Osječko-baranjska & $49, I I(7)$ & $46,07(7)$ & $49,2 \mathrm{I}(7)$ & $\langle 0,47 ; 0,52\rangle$ & $\langle 0,44 ; 0,48\rangle$ & $\langle 0,48 ; 0,5 \mathrm{I}\rangle$ \\
\hline Karlovačka & $53,28(9)$ & $56,34(8)$ & $54,47(9)$ & $\langle 0,49 ; 0,57\rangle$ & $\langle 0,54 ; 0,59\rangle$ & $\langle 0,52 ; 0,57\rangle$ \\
\hline Koprivničko-križevačka & $52,63(8)$ & $59,19(9)$ & $5 I, 64(8)$ & $\langle 0,46 ; 0,59\rangle$ & $\langle 0,55 ; 0,64\rangle$ & $\langle 0,48 ; 0,56\rangle$ \\
\hline Ličko-senjska & 59,6 I (IO) & 64,82 (IO) & 6I,O4 (IO) & $<0,54 ; 0,65\rangle$ & $\langle 0,6 \mathrm{I} ; \mathrm{o}, 68\rangle$ & $\langle 0,58 ; 0,64\rangle$ \\
\hline Međimurska & $64,79(12)$ & $69,65(\mathrm{II})$ & $62,03(12)$ & $\langle 0,58 ; 0,72\rangle$ & $\langle 0,64 ; 0,75\rangle$ & $\langle 0,58 ; 0,66\rangle$ \\
\hline Krapinsko-zagorska & $62,78(\mathrm{I} 2)$ & 73,24 (I2) & $6 \mathrm{I}, 45(\mathrm{II})$ & $\langle 0,56 ; 0,69\rangle$ & $\langle 0,68 ; 0,78\rangle$ & $\langle 0,58 ; 0,66\rangle$ \\
\hline Šibensko-kninska & $83,04(\mathrm{I} 4)$ & $80,93(13)$ & $82, \mathrm{I} 4$ (I4) & $\langle 0,80 ; 0,87\rangle$ & $\langle 0,79 ; 0,83\rangle$ & $\langle 0,80 ; 0,84\rangle$ \\
\hline Varaždinska & $78,8 \mathrm{I}(\mathrm{I} 3)$ & 86,34 (I4) & $77,39(13)$ & $\langle 0,73 ; 0,84\rangle$ & $\langle 0,82 ; 0,90\rangle$ & $\langle 0,74 ; 0,8 \mathrm{I}\rangle$ \\
\hline Splitsko-dalmatinska & IO2,55 (I5) & $93,75(15)$ & IOI,2 (I5) & $\langle 0,97 ; \mathrm{I}, 09\rangle$ & $\langle 0,90 ; 0,98\rangle$ & $\langle 0,98 ; \mathrm{I}, 05\rangle$ \\
\hline Zadarska & $\mathrm{II} 2,62$ (I6) & IO6,39 (I6) & IO9,I3 (I6) & $\langle\mathrm{I}, \mathrm{O} 4 ; \mathrm{I}, 23\rangle$ & $\langle\mathrm{I}, \mathrm{OI} ; \mathrm{I}, \mathrm{I} 2\rangle$ & $\langle\mathrm{I}, \mathrm{O} 4 ; \mathrm{I}, \mathrm{I} 4\rangle$ \\
\hline Dubrovačko-neretvanska & $\mathrm{I} 23,62(\mathrm{I} 8)$ & $\mathrm{I} 2 \mathrm{O}, 84(\mathrm{I} 7)$ & I22,3I (I8) & $\langle\mathrm{I}, 2 ; \mathrm{I}, 28\rangle$ & $\langle\mathrm{I}, \mathrm{I} 8 ; \mathrm{I}, 23\rangle$ & $\langle\mathrm{I}, 2 \mathrm{O} ; \mathrm{I}, 25\rangle$ \\
\hline Zagrebačka & I2I,2I (I7) & $\mathrm{I} 24,23(\mathrm{I} 8)$ & II8,O3 (I7) & $\langle\mathrm{I}, \mathrm{I} 5 ; \mathrm{I}, 28\rangle$ & $\langle\mathrm{I}, 2 \mathrm{I} ; \mathrm{I}, 28\rangle$ & $\langle\mathrm{I}, \mathrm{I} 4 ; \mathrm{I}, 22\rangle$ \\
\hline Primorsko-goranska & I39,69 (I9) & I39,2I (I9) & I4I,7I (I9) & $\langle\mathrm{I}, 35 ; \mathrm{I}, 44\rangle$ & $\langle\mathrm{I}, 37 ; \mathrm{I}, 4 \mathrm{I}\rangle$ & $\langle\mathrm{I}, 39 ; \mathrm{I}, 44\rangle$ \\
\hline Istarska & $\mathrm{I} 54,36(20)$ & I56,80 (2O) & I54,2O (2O) & $\langle\mathrm{I}, 5 ; \mathrm{I}, 59\rangle$ & $\langle\mathrm{I}, 54 ; \mathrm{I}, 6\rangle$ & $\langle\mathrm{I}, 5 \mathrm{I} ; \mathrm{I}, 57\rangle$ \\
\hline Grad Zagreb & $\mathrm{I} 85,45(2 \mathrm{I})$ & $\mathrm{I} 86,44(2 \mathrm{I})$ & $\mathrm{I} 88,5(2 \mathrm{I})$ & $\langle\mathrm{I}, 76 ; \mathrm{I}, 93\rangle$ & $\langle\mathrm{I}, 8 \mathrm{I} ; \mathrm{I}, 92\rangle$ & $\langle\mathrm{I}, 83 ; \mathrm{I}, 93\rangle$ \\
\hline
\end{tabular}

PI - intervalne procjene.

Izvor: izračun autorica.

\subsection{ANALIZA OSJETLJIVOSTI INDEKSA RAZVIJENOSTI}

\subsection{ANALIZA OSJETLJIVOSTI INDEKSA RAZVIJENOSTI JEDINICA LOKALNE SAMOUPRVE}

Za pokazatelje $X_{i}, \mathrm{i}=\mathbf{I}, 2, \ldots, 5$ indeksa razvijenosti izračunate su vrijednosti indeksa osjetljivosti prvog stupnja $S_{i}$ i ukupnog indeksa osjetljivosti $S_{T_{i}}$. U tablici II dani su rezultati na razini JLS-a.

Može se zaključiti kako promjena u vrijednostima jednog pokazatelja putem interakcija s ostalim pokazateljima kumulativno utječe na vrijednost indeksa razvijenosti. Znatno veće vrijednosti ukupnog indeksa osjetljivosti ukazuju na jači utjecaj interakcija ekonomskih pokazatelja: izvornih prihoda per capita, dohotka per capita i stope nezaposlenosti. 
TABLICA II.

Indeksi osjetljivosti (JLS razina)

\begin{tabular}{ccccccc}
$\mathbf{I}$ & $\mathbf{I}$ & $\mathbf{2}$ & $\mathbf{3}$ & $\mathbf{4}$ & $\mathbf{5}$ & \\
\hline$S_{i}$ & 0,084 & $0, \mathrm{I} 45$ & 0,087 & $0,02 \mathrm{I}$ & 0,022 \\
\hline$S_{T_{i}}$ & 0,394 & 0,485 & 0,390 & 0,155 & 0,216 \\
\hline
\end{tabular}

Izvor: izračun autorica.

Pitanje osjetljivosti indeksa na male promjene ekonomskih pokazatelja ispitano je direktno Monte Carlo simulacijama. Za svaku jedinicu $c$ generirano je Ioo vrijednosti pokazatelja $X_{i} i=1, \ldots, 5 \mathrm{iz}$ normalne razdiobe s očekivanjem jednakim stvarnoj vrijednosti pokazatelja $x_{c i}$ i četvrtinom uzoračke varijance $\sigma_{i}^{2}$ pokazatelja procijenjene na temelju vrijednosti svih jedinica. Time smo se ograničile na manje perturbacije parametara koje mogu biti rezultat promjena vrijednosti u kraćim vremenskim razdobljima ili kao posljedica nepreciznosti mjerenja.

GRAFIKON 3.

Intervalne procjene

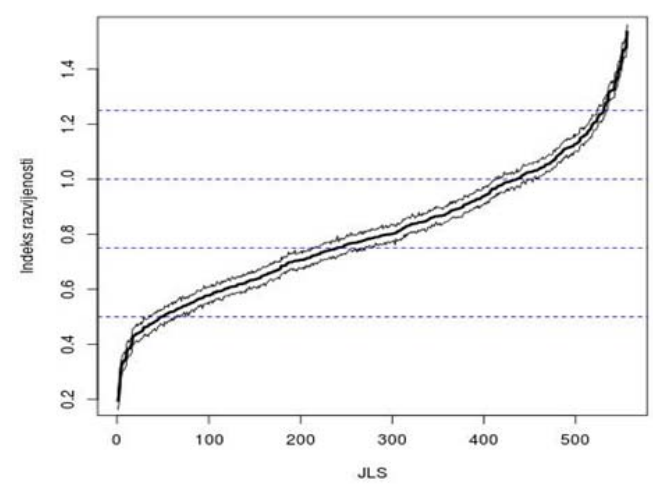

Izvor: izračun autorica.
TABLICA I2.

Postotak promjene skupine

\begin{tabular}{ccc} 
Skupina prema & $\begin{array}{c}\text { \% prelaska u } \\
\text { nižu skupinu }\end{array} I^{N V}$ & $\begin{array}{c}\text { \% prelaska u } \\
\text { višu skupinu }\end{array}$ \\
\hline I & - & I9 \\
\hline II & 9 & I2 \\
\hline III & I5 & I2 \\
\hline IV & I5 & 7 \\
\hline V & 8 & - \\
\hline
\end{tabular}

Izvor: izračun autorica.

U grafikonu 3 prikazana je vrijednost indeksa razvijenosti JLS-a, zajedno s njegovom intervalnom procjenom uz razinu pouzdanosti 95\% dobivenom putem simulacija. Sjecištima granica skupina određenih s $I^{N V}$ i intervalnih procjena određene su JLS-i koji prelaze u višu odnosno nižu skupinu te se u tablici 12 nalaze postotci prelaska u skupine. Na tim jedinicama potrebno je provesti detaljniju pojedinačnu analizu zbog veće vjerojatnosti pogrešne kategorizacije.

\subsubsection{ANALIZA OSJETLJIVOSTI INDEKSA RAZVIJENOSTI JEDINICA REGIONALNE SAMOUPRAVE}

Za pokazatelje $X_{i}, \mathrm{i}=\mathrm{I}, 2, \ldots, 5$ indeksa razvijenosti izračunate su vrijednosti indeksa osjetljivosti prvog stupnja $S_{i}$ i ukupnog indeksa osjetljivosti $S_{T_{i}}$. U tablici I3 dani su rezultati na razini JRS-a.

\section{TABLICA I3.}

Indeksi osjetljivosti (JRS razina)

\begin{tabular}{|c|c|c|c|c|c|}
\hline I & $\mathbf{I}$ & 2 & 3 & 4 & 5 \\
\hline$S_{i}$ & 0,084 & 0,039 & O,II9 & $\mathrm{O}, \mathrm{O} 2 \mathrm{I}$ & $\mathrm{O}, \mathrm{O} 22$ \\
\hline$S_{T_{i}}$ & 0,439 & 0,322 & $0,48 \mathrm{I}$ & 0,239 & $0,22 \mathrm{I}$ \\
\hline
\end{tabular}

Izvor: izračun autorica. 
Slično kao u analizi osjetljivosti JLS-a, kao najveći uzročnik varijabilnosti indeksa razvijenosti izdvaja se interakcija ekonomskih pokazatelja. Simulacijom vrijednosti tih pokazatelja, analogno simulacijama za JLS-e, dobivene su intervalne procjene na razini pouzdanosti 95\% te su za svaki JRS prikazani u grafikonu 4.

\section{GRAFIKON 4.}

Intervalne procjene (razina JRS-a)

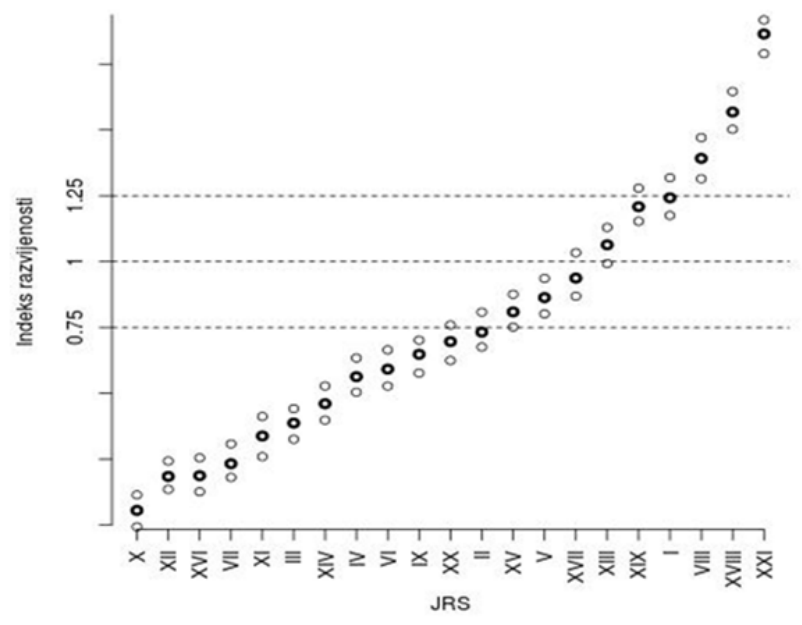

Izvor: izračun autorica.

Intervalne procjene indeksa razvijenosti Krapinsko-zagorske, Splitsko-dalmatinske, Dubrovačkoneretvanske i Zagrebačke županije ulaze $u$ kategorije višeg stupnja razvoja u odnosu na kategoriju dodijeljenu indeksom $I^{V}$. Stoga se može zaključiti kako su navedene županije moguće podcijenjene indeksom razvijenosti $I^{V}$ te se otvara potreba za pobližom individualnom analizom tih županija. Korištenje intervalnih procjena otvara mogućnosti za pobližu analizu ovakvih rubnih slučajeva, uzimajući u obzir vjerojatnosnu procjenu pogrešne kategorizacije teritorijalnih jedinica.

\section{ZAKLJUČAK}

Do donošenja indeksa razvijenosti, sustav za ocjenjivanje i kategorizaciju teritorijalnih jedinica koje zaostaju u razvoju često je bio ocjenjivan kao neujednačen i fragmentiran. Preokret u kategorizaciji donosi indeks razvijenosti prema kojemu se razvijenost jedinica lokalne i regionalne samouprave računa kao ponderirani prosjek odstupanja normaliziranih vrijednosti pokazatelja od prosjeka Hrvatske. Kategorizacija jedinica na temelju indeksa razvijenosti sa sobom donosi prava na mnoge olakšice i državne poticaje stoga je za mnoge lokalne jedinice koje zaostaju u razvoju ključna za daljnji razvoj.

Osnovni ciljevi rada bili su ispitati neizvjesnost indeksa s obzirom na metodološki pristup, ispitati osjetljivost indeksa $\mathrm{s}$ obzirom na pokazatelje uključene $\mathrm{u}$ izračun te dati korisne smjernice za unaprjeđenje indeksa. U radu je prikazana metodologija izračuna indeksa razvijenosti, te je primjenom multivarijatne analize utvrđena struktura pokazatelja. Rezultati multivarijatne analize ukazuju na postojanje izdvojenica. Također, primjenom multivarijatne analize na županijskoj razini uočeno je postojanje kolinearnosti pokazatelja dohodak per capita i prosječni izvorni prihodi per 
capita koje je moguće zaobići isključivanjem ili zamjenom alternativnim pokazateljima ili korekcijom pondera pokazatelja.

Subjektivne odluke istraživača, kao što su izbor metode normalizacije i agregacije, te odabir pokazatelja i pondera, igraju veliku ulogu pri konstrukciji kompozitnog indeksa. Stoga je nužno detektirati moguće izvore nepouzdanosti i analizirati njihove posljedice. Manjak konsenzusa o relativnim ponderima svojstvo je koje prati konstrukciju kompozitnih pokazatelja. U radu je, s obzirom na vrijednosti pondera, kao referentni indeks predložen indeks razvijenosti dobiven direktno iz podataka metodom analize glavnih komponenata. Dakle, $u$ referentnom indeksu eliminirana je subjektivnost u odabiru pondera. Neizvjesnost indeksa razvijenosti ispitana je obzirom na glavne izvore neizvjesnosti te pomoću Monte Carlo simulacija posebno na izbor pondera. Uočen je problem nemogućnosti ujednačenog rangiranja JLS-a prema indeksu razvijenosti s posebnim naglaskom na JLS koje su prema indeksu razvijenosti Vlade kategorizirane u II. i III. skupinu. Kategorizacija temeljem indeksa pokazala se manje pouzdanom u odnosu na AGK kategorizaciju s obzirom na odabir pondera kao izvor neizvjesnosti.

U analizi osjetljivosti modela određenog odlukom Vlade uočene su jake interakcije ekonomskih pokazatelja koje dominantno utječu na varijabilnost indeksa razvijenosti JLS-a i JRS-a. Obzirom da i male perturbacije vrijednosti ulaznih varijabli mogu značajno utjecati na ishod kategorizacije, poseban naglasak je stavljen na uključivanje ovih metoda u razvoj kompozitnog indeksa. Kako su greške u mjerenjima pokazatelja česte, a kod pojedinih pokazatelja nerijetko nisu ni pravovremeno dostupni stvarni podaci, nužna je potreba za uključivanjem tih nesigurnosti u model. U tu svrhu predlaže se promatranje intervalnih procjena nasuprot procjene razine razvijenosti jednim brojem. $\mathrm{Na}$ taj način moguće je u model uključiti neizvjesnosti te se rubni slučajevi indeksa mogu pobliže analizirati (primjerice teritorijalne jedinice s vrijednostima indeksa koje odstupaju za 5 postotnih bodova od graničnih vrijednosti kategorizacija).

U manjku znanstvenih radova na ovu temu, namjera autorica bila je istaknuti potrebu za ispitivanjem osjetljivosti i neizvjesnosti indeksa razvijenosti te kompozitnih pokazatelja općenito. Obzirom na široku i sve veću primjenu kompozitnih pokazatelja, ovaj rad nudi smjernice za razvoj i primjenu analize osjetljivosti i neizvjesnosti kompozitnih indikatora i u drugim područjima znanosti i struke.

Za tri godine očekuje se novi izračun indeksa razvijenosti. Bit će zanimljivo pratiti kako se razvija metodologija indeksa, kako u odabiru pokazatelja i njihovoj kvaliteti, tako i u ocjenjivanju njihove relativne važnosti s obzirom na socio-ekonomske uvjete $u$ državi. U cilju općeg prihvaćanja indeksa razvijenosti, nužno je cijeli proces konstrukcije indeksa učiniti transparentnim. Metodologija izračuna budućeg indeksa razvijenosti trebala bi pratiti očekivane promjene u dinamici i interakciji pokazatelja, kako bi se osigurao moderan pristup ocjenjivanju razvijenosti teritorijalnih jedinica. 


\section{DODATAK}

\section{OSNOVNE SMJERNICE ZA POBOLJŠANJE METODOLOGIJE INDEKSA}

I) Koreliranost pokazatelja dohodak per capita i prosječni izvorni prihodi per capita korigirati na jedan od načina:

a) korekcijom pondera ,

b) isključivanjem jednog od pokazatelja,

c) zamjenom alternativnim pokazateljima.

$\mathrm{Na}$ županijskoj razini razmotriti uključivanje pokazatelja BDP per capita kao ključnog ekonomskog pokazatelja.

2) Prilikom korištenja min-max normalizacije isključiti izdvojenice. Razmotriti korištenje predložene alternativne normalizacije obzirom na indeks države danom formulom (I3).

3) Razmotriti alternativne metode ponderiranja te provesti analizu neizvjesnosti i osjetljivosti u svrhu poboljšanja transparentnosti te povećanja kvalitete indeksa razvijenosti.

4) Prethodno kategorizaciji JLS-a odnosno JRS-a procijeniti intervale za vrijednost indeksa razvijenosti JLS-a odnosno JRS-a. Ako se granice kategorija potpomognutih skupina nalaze unutar intervalnih procjena teritorijalne jedinice koja nije svrstana u potpomognuta područja, potrebno je pobliže analizirati pokazatelje iste jedinice kako bi se izbjegla pogrešna kategorizacija.

5) Razmotriti moguće uključivanje/isključivanje rubnih JLS-a u/iz područja koja zaostaju u razvoju. Analizu provesti temeljem vjerojatnosti kategorizacije procijenjene Monte Carlo simulacijama (vidjeti odjeljak 4.4.).

5.I) Obzirom na rezultate simulacija razmotriti uključenje JLS-a danih u tablici AI u skupinu II, tj. u područja koja zaostaju u razvoju. U tablici su također dane i vrijednosti indeksa razvijenosti i rezultati kategorizacije u pojedine skupine temeljem MC simulacija $S_{I}$ (vidjeti odjeljak 4.4.I.).

TABLica AI.

Prijedlog za uključenje JLS-a u skupine koje zaostaju u razvoju

\begin{tabular}{|c|c|c|c|}
\hline \multirow{2}{*}{ JLS-i } & \multirow{2}{*}{$\begin{array}{c}\text { Indeks } \\
\text { razvijenosti }\end{array}$} & \multicolumn{2}{|c|}{ \% kategorizacije u skupinu } \\
\hline & & II & III \\
\hline Ozalj & 0,7508 & 0,876 & O,I24 \\
\hline Donji Vidovec & 0,7517 & 0,902 & 0,098 \\
\hline Jesenje & 0,7522 & 0,860 & $\mathrm{O}, \mathrm{I} 4 \mathrm{O}$ \\
\hline Sveti Martin na Muri & 0,7525 & 0,760 & 0,240 \\
\hline Lećevica & 0,7537 & 0,980 & 0,020 \\
\hline Petrijanec & 0,7543 & 0,788 & 0,212 \\
\hline Donji Miholjac & 0,7612 & 0,546 & 0,454 \\
\hline Krašić & 0,7624 & 0,942 & 0,058 \\
\hline Klenovnik & $0,767 \mathrm{I}$ & 0,742 & 0,258 \\
\hline Vratišinec & $0,768 \mathrm{I}$ & 0,676 & 0,324 \\
\hline Hrašćina & 0,7683 & 0,862 & O,I38 \\
\hline Pregrada & 0,7688 & 0,872 & O,I28 \\
\hline Đelekovec & 0,7689 & 0,926 & 0,074 \\
\hline Lepoglava & 0,7695 & 0,584 & 0,416 \\
\hline
\end{tabular}




\begin{tabular}{lcccc} 
JLS-i & $\begin{array}{c}\text { Indeks } \\
\text { razvijenosti }\end{array}$ & \% kategorizacije u skupinu & III \\
\hline Kraljevec na Sutli & 0,7700 & I & 0,802 & 0,198 \\
\hline Mače & 0,7728 & 0,766 & 0,234 \\
\hline Jalžabet & 0,7775 & 0,550 & 0,450 \\
\hline Đurmanec & 0,7829 & 0,570 & 0,430 \\
\hline Breznički Hum & 0,7856 & 0,756 & 0,244 \\
\hline Bedenica & 0,7901 & 0,562 & 0,438 \\
\hline Veliki Bukovec & 0,8231 & 0,526 & 0,474 \\
\hline
\end{tabular}

5.2) Obzirom na rezultate simulacija razmotriti isključenje JLS-a danih $u$ donjoj tablici iz područja koja zaostaju u razvoju i kategorizaciju u skupinu III. U tablici su također dane i vrijednosti indeksa razvijenosti i rezultati kategorizacije u pojedine skupine temeljem MC simulacija $S_{\text {I }}$ (vidjeti odjeljak 4.4.I.).

\section{TABLIGA A2.}

Prijedlog za isključenje JLS-a iz skupina koje zaostaju u razvoju

\begin{tabular}{lccccc} 
JLS-i & Indeks razvijenosti & \% kategorizacije u skupinu \\
\hline Vrsi & 0,728 & II & III & 0,824 \\
\hline Imotski & 0,7353 & 0,176 & 0,794 \\
\hline Nova Gradiška & 0,7413 & 0,206 & 0,544 \\
\hline Beli Manastir & & 0,456 & 0,608 \\
\hline
\end{tabular}

${ }^{a}$ PPDS, nekorigiranim indeksom ne ulazi u potpomognuta područja.

6) Iako u radu nije posebno analizirano, korisno bi bilo razmotriti i alternativnu metodu agregacije, pogotovo geometrijsku agregaciju zbog ograničavanja kompenzacije između varijabli. 


\section{REFERENGE}

I. Bahovec, V. i Erjavec, N., 20o9. Uvod u ekonometrijsku analizu. Zagreb: Element.

2. Bajo, A. i Primorac, M., 2013. "Package of legislative amendments for a better Croatian regional policy”. Press Relase, Br. 6I. doi: I0.3326/pr.20I3.6I

3. Ben Gal, I., 2005. Outlier detection. U: O. Maimon and L. Rockach, ur. Data mining Knowledge Discovery Handbook: A Complete Guide for Practitioners and Researchers. Kluwer Academic Publishers. doi: IO.I007/O-387-25465-X_7

4. Booysen, F., 2002. "An overview and evaluation of composite indices of development". Social indicators research, 59 (2), str. II5-I5I. doi: IO.IO23/A:IOI6275505I52

5. Bronić, M., 2008. “The Croatian Ministry of Finance's Current Grants to Municipalities and Cities in the Areas of Special National Concern". Newsletter, Br. 35 [pdf]. Dostupno na: 〈http://www.ijf.hr/eng/newsletter/35.pdf〉.

6. Bronić, M., 20Io. "Evaluating the current equalization grant to counties in Croatia”. Financial Theory and Practice, 34 (I), str. 25-52 [pdf]. Dostupno na: <http://fintp.hr/upload/files/ftp/2OIO/I/bronic.pdf>.

7. Cziraky, D. [et al.], 2003. An econometric model for development level assessment with an application to municipality development classification. U: Z. Reić, ur. Enterprise in transition: proceedings of the 5th Conference on Enterprise in transition. Split: Ekonomski fakultet.

8. Cziraky, D. [et al.], 2005. Regional development assessment: A structural equation approach. European Journal of Operational Research, I74 (I), str. 427-442. doi: Io.IoI6/j.ejor.2005.03.0I2

9. Foa, R. i Tanner, J. C., 20I2. "Methodology of the Indices of Social Development". Institute of Social Studies, Working Paper Series [pdf]. Dostupno na: <http://www.indsocdev.org/resources/Methodology\%2Oof\%2othe\%20Social\%2oDevelopment\%2oIndices_\%20janir.pdf >.

IO. Gall, M., 2007. Indices of social vulnerability to natural hazards: A comparative evaluation. Doctoral thesis. University of South Carolina.

II. Grčić, B. i Filipić, P., 2002. "Evaluation of regional development and (im)balances: the Croatian case”. The Journal of Management Sciences \& Regional Development, I2 (7), str. 2I-36.

I2. Gujarati, D. N., 2004. Basic econometrics. New York: McGraw-Hill Companies.

I3. Hair, J. F. [et al.], 1995. Multivariate data analysis: with readings. New Jersey: Prentice Hall.

I4. Hoyland, B., Moene, K. i Willumsen, F., 2OI2. "The tyranny of international index rankings". Journal of Development economics, 97 (I), str. I-I4. doi: I0.IOI6/j.jdeveco.20II.0I.007

I5. Maleković, S., Puljiz, J. i Tišma, S., 20II. "New opportunities for regional and local actors in Croatia in supporting socio-economic development". Southeastern Europe, 35, str. I68-I9o. doi: IO.II63/I876333IIX 585360

I6. MRRFEU, 20IOa. Vrijednosti indeksa razvijenosti i pokazatelja za izračun indeksa razvijenosti na lokalnoj razini [pdf]. Dostupno na: <http://www.mrrfeu.hr/default.aspx?id=405>. Zagreb: Ministarstvo regionalnog razvoja i fondova Europske unije.

17. MRRFEU, 20Iob. Vrijednosti indeksa razvijenosti i pokazatelja za izračun indeksa razvijenosti na županijskoj razini [pdf]. Dostupno na: 〈http://www.mrrfeu.hr/default.aspx?id=405>. Zagreb: Ministarstvo regionalnog razvoja i fondova Europske unije.

I8. MRRFEU, 2OI2. Strateški plan za razdoblje 20I2.-2OI4. Zagreb: Ministarstvo regionalnog razvoja i fondova Europske unije.

19. MRRFEU, 20I3a. Vrijednosti indeksa razvijenosti i pokazatelja za izračun indeksa razvijenosti na lokalnoj razini [pdf]. Dostupno na: <http://www.mrrfeu.hr/default.aspx?id=405>. Zagreb: Ministarstvo regionalnog razvoja i fondova Europske unije.

20. MRRFEU, 2013b. Vrijednosti indeksa razvijenosti i pokazatelja za izračun indeksa razvijenosti na županijskoj razini [pdf]. Dostupno na: 〈http://www.mrrfeu.hr/default.aspx?id=405〉. Zagreb: Ministarstvo regionalnog razvoja i fondova Europske unije.

2I. MRRFEU, 20I3c. Glavne novine koje donosi Nacrt prijedloga Zakona o regionalnom razvoju Republike Hrvatske [online]. Dostupno na: <www.mrrfeu.hr/default.aspx?id=I674>. Zagreb: Ministarstvo regionalnog razvoja i fondova Europske unije.

22. Nardo, M. [et al.], 2005. Tools for Composite Indicators Building. Ispra: Joint Research Centre.

23. Nardo, M. [et al.], 2008. Handbook on constructing composite indicators [pdf]. Dostupno na: 〈http://www.oecd.org/std/42495745.pdf〉.

24. Noorbakhsh, F., 1998. "The human Development index: Some technical issues and alternative indices”. Journal of International Development, Io (5), str. 589-605. doi: IO.IOO2/(SICI)IO99I328(I99807/O8)IO:5<589::AID-JID484>3.0.CO;2-S 
25. Oreskes, N., Shrader-Frechette, K. i Belitz, K., I994. „Verification, validation and confirmation of numerical models in the earth sciences". Science, 263 (5I47), str. 64I-646. doi: I0.II26/science.263.5I47.64I

26. Ott, K. i Bajo, A., 200I. "Lokalne financije i lokalni proračuni u Republici Hrvatskoj”. Financijska teorija i praksa, 25 (3), str. 3II-434.

27. Ott, K., 2009. Proračunski vodič za građane. Zagreb: Institut za javne financije.

28. Paruolo, P., Saisana, M. and Saltelli, A. 2013. "Ratings and rankings: voodoo or science?". Journal of the Royal Statistical Society: Series A (Statistics in Society), 176: str. 609-634. doi: IO.IIII/j.I467985X.2OI2.OIO59.X

29. Perišić, A., 2OI4. "Multivariate Classification of Local and Regional Government Units According to Socio-Economic Development”. Društvena istraživanja, 23 (2), str. 2II-23I. doi: Io.5559/di.23.2.0I

30. Puljiz, J. [et al.], 2005. Novi pristup ocjenjivanju i kategorizaciji teritorijalnih jedinica prema razvijenosti. Zagreb: Institut za međunarodne odnose.

3I. Puljiz, J., 2007. Proposal for new development categorisation on regional and local units in Croatia. [pdf] Croatian international relations review, I2 (44/45), str. 125-138.

32. Puljiz, J., 2009. Čimbenici regionalnog razvoja i regionalnih nejednakosti u Republici Hrvatskoj. Doktorska disertacija. Split: Ekonomski fakultet.

33. Rimac, I., Rihtar, S. i Oliveira Roca, M. 1992. „Multivarijatna klasifikacija općina Hrvatske kao moguća metoda regionalizacije Republike”. Društvena istraživanja, I (I), str. 87-99.

34. Rosen, R., I99I. Life Itself: A Comprehensive Inquiry into Nature, Origin, and Fabrication of Life. Columbia University Press.

35. Saisana, M. i Saltelli, A., 2008. Expert Panel Opinion and Global Sensitivity Analysis for Composite Indicators. U: F. Graziani, ur. Computational Methods in Transport: Verification and Validation. Springer Berlin Heidelberg, str. 25I.-275. doi: IO.IOO7/978-3-540-77362-7_II

36. Saisana, M., Saltelli, A. i Tarantola, S., 2005. "Uncertainty and sensitivity analysis techniques as tools for the quality assessment of composite indicators". Journal of the Royal Statistical Society - A, I68 (2), str. 307-323.

37. Saltelli, A. [et al.], 2004. Sensitivity Analysis in Practice: A Guide to Assessing Scientific Models. New York: John Wiley \& Sons.

38. Saltelli, A. [et al.], 2008. Global Sensitivity Analysis. The Primer. New York: John Wiley \& Sons.

39. Salzman J., 2003. Methodological choices encounterd in the construction of composite indices of economic and social well-being [pdf]. Dostupno na: <http://www.csls.ca/events/cea2oo3/salzmantypol-cea2003.pdf>.

40. Sharpe A., 2004. Literature Review of Frameworks for Macro-indicators. Ottawa: Centre for the Study of Living Standards.

4I. Sumpor, M., Jurlina Alibegović, D. i Đokić, I., 20I2. Ocjena sustava strateškog planiranja i mogućnosti financiranja razvoja županija i lokalnih jedinica u kontekstu provođenja politike regionalnog razvoja Republike Hrvatske. Zagreb: Ekonomski institut Zagreb.

42. Tarantola, S., Jesinghaus, J. i Puolamaa, M., 2000. Global sensitivity analysis: a quality assurance tool in environmental policy modelling. U: A. Saltelli, K. Chan and M. Scott, ur. Sensitivity analysis. New York: John Wiley \& Sons, str. 385.-397.

43. Toffalis, C., 2013. "An automatic-democratic approach to weight setting for the new human Development index”. Journal Population Economy, 26 (4), str. 1325-I345. doi: IO.IOO7/sooI48-OI20432-x

44. United Nations, 1969. Social policy and planning in national development. Report of the Meeting of Experts on Social Policy and Planning. Geneva: United Nations Economic and Social Council Commision for Social Development.

45. Uredba o indeksu razvijenosti, NN 63/Io. Zagreb: Narodne novine.

46. Uredba o izmjeni i dopunama Uredbe o indeksu razvijenosti, NN 158/2OI3. Zagreb: Narodne novine.

47. Zakon o brdsko-planinskim područjima, NN I2/O2, 32/O2, II7/O3, 42/O5, 90/O5, 80/o8 i I48/13. Zagreb: Narodne novine.

48. Zakon o regionalnom razvoju, NN 153/og. Zagreb: Narodne novine. 